\title{
THE OHIO STATE UNIVERSITY
}

\section{RESEARCH FOUNDATION 1314 KINNEAR ROAD COLUMBUS, OHIO 43212}

Repur.l C00-131y-24

\author{
A STUDY OF THE MECHANISM OF STRESS CORROSION \\ CRACKING IN THE IRON-NICKEL-CHROMIUM ALLOY SYSTEM \\ R. W. Staehle, F. H. Beck, M. G. Fontana, and J. P. Hirth \\ Department of Metallurgical Engineering
}
U. S. ATOMIC ENERGY COMMISSION
Chicago Operations office Argonne, Illinois

Contract No. AT(11-1)-1319 


\section{DISCLAIMER}

This report was prepared as an account of work sponsored by an agency of the United States Government. Neither the United States Government nor any agency Thereof, nor any of their employees, makes any warranty, express or implied, or assumes any legal liability or responsibility for the accuracy, completeness, or usefulness of any information, apparatus, product, or process disclosed, or represents that its use would not infringe privately owned rights. Reference herein to any specific commercial product, process, or service by trade name, trademark, manufacturer, or otherwise does not necessarily constitute or imply its endorsement, recommendation, or favoring by the United States Government or any agency thereof. The views and opinions of authors expressed herein do not necessarily state or reflect those of the United States Government or any agency thereof. 


\section{DISCLAIMER}

Portions of this document may be illegible in electronic image products. Images are produced from the best available original document. 


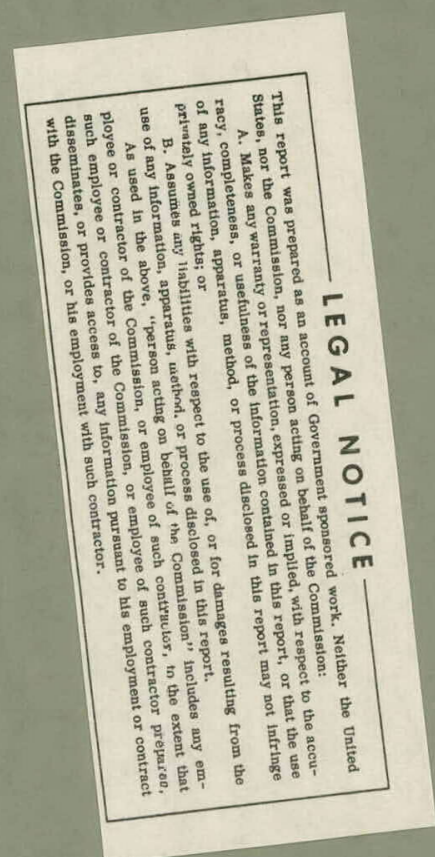


RF Project $\quad 1673$

Report No... Coo-1319-24

\section{R E P O R T}

\section{By \\ THE OHIO STATE UNIVERSITY \\ RESEARCH FOUNDATION}

1314 KINNEAR RD.

COLUMBUS, OHIO 43212

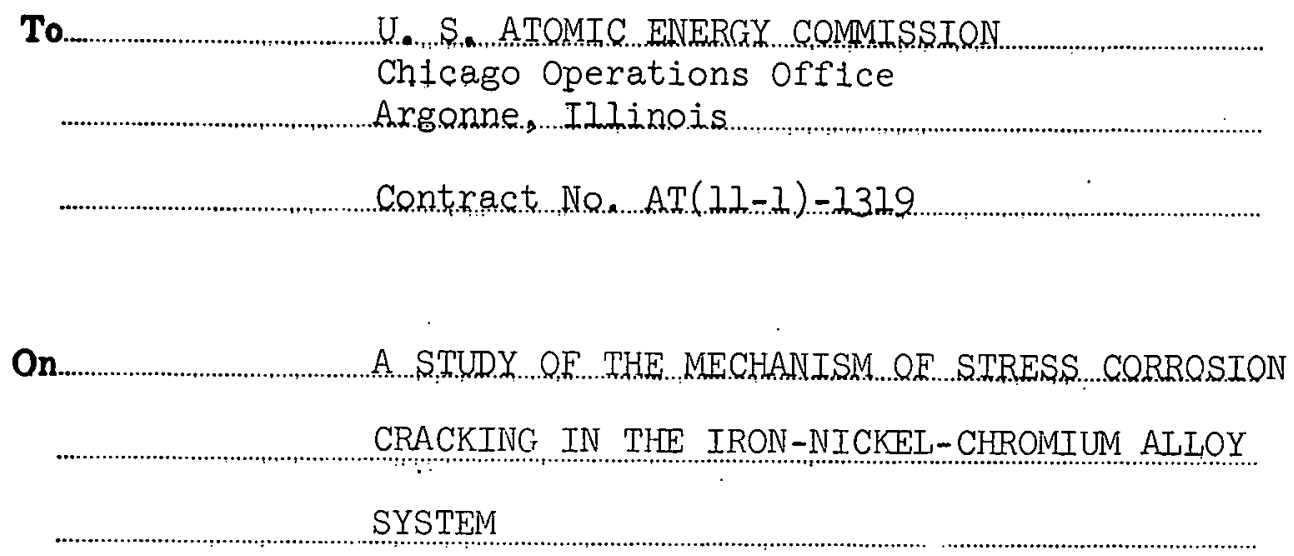

For the period................... December 1964-16 March 1965
Submitted by ............ R. W. Staehle, F. H. Beck, M. G. Fontana, and J. P. Hirth
Department of Metallurgical Engineering

Date......................... 


\section{INI'RODUCTION}

The aims of this program are (I) to evaluate systematically the susceptibility of iron-nickel-chromium alloys to stress-corrosion cracking in chloride- and hydroxide-containing environments, and (2) to establish a reliable model for stress-corrosion cracking in iron-chromium-nickel alloys. The general experimental program is evaluating commercial and specially prepared alloys over the range of iron and nickel ratios and up to $40 \%$ chromium. Studies are being conducted in the areas of stress-corrosion experiments, electrochemistry, and physical metallurgy. Important objectives of this program are (1) to integrate the studies in the stress corrosion, physical metallurgy, and electrochemical areas; and (2) to conduct the studies with a high degree of self-consistency. Through this approach it is expected that the model for cracking which is eventually developed will have a. high degree of credibility.

\section{STRESS-CORROSION CRACKING EXPERIMENTS}

\section{A. RECIRCULATING AUTOCLAVE SYSTEM}

During the past quarter additional work has been required to "de-bug" the circulating autoclave system. This has involved mainly work on timeto-cracking circuitry, safety interlocks activated by temperature and pressure alarms, pump control, pressure seals, and stressing jigs. It appears that the system is now ready for running preliminary experiments and these should begin shortly.

\section{B. SCOPING STUDIES OF ALLOY COMPOSITION}

The autoclave protion of a preliminary scoping study of commercial and special alloys is about complete in a $600^{\circ} \mathrm{F}, 0.1 \mathrm{w} / 0 \mathrm{NaCl}, 100 \mathrm{psi}$ oxygen over pressure environment. The details of this experiment were described in the previous progress report. Available additional results are summarized in Table I. The wires used in these tests are 0.015 -inch diameter and have received identical fabrication treatments. The final treatment is to strand anneal at $2200^{\circ} \mathrm{F}$. The stay time in the furnace is approximately 10 seconds following which they are quenched. Specimens are exposed in these scoping studies using their as-received surface. Studies of effects of special surface preparations will be undertaken at a later date.

Figure 1 shows alloy 2 (95 $\mathrm{Fe}-5 \mathrm{Ni}$ ) in the stressed and non-stressed conditions. Both alloys are about equally oxidized and stress appears to have little effect.

Figure 2 shows alloy $33(55 \mathrm{Fe}-35 \mathrm{Ni}-10 \mathrm{Cr}$ ). The non-stressed specimen has no obvious surface oxidation or localized chemical attack. The stressed specimen exhibits both unfform oxidation and intergranular cracking. 
Table I. Results from Experiments at $600^{\circ} \mathrm{F}$ in $0.1 \mathrm{w} / \mathrm{O} \mathrm{NaCl}$ Solution and 100 psi Oxygen Overpressure (Specimens stresses initially to 40,000 psi except where noted $)^{1}-24$-Hour Test Period

\begin{tabular}{|c|c|c|c|c|c|c|c|}
\hline $\begin{array}{l}\text { Specimen } \\
\text { No. }\end{array}$ & $\begin{array}{c}\text { Alloy } \\
\text { Designation }\end{array}$ & $\frac{\mathrm{Alloy}}{\mathrm{Fe}}$ & $\frac{\text { Compos }}{\mathrm{Ni}}$ & $\frac{\mathrm{tion},}{\mathrm{Cr}}$ & $\frac{\text { Atomic } \% 2}{\text { Other }}$ & Fail $^{3}, 4$ & Comments $^{6}$ \\
\hline $18-1$ & $50-\mathrm{Ti}$ & 7.9 & 75.8 & 14.8 & $1.5 \mathrm{Ti}$ & end & Stressed specimen pitted \\
\hline $18-2$ & $54-\mathrm{Zn}$ & 64 & 14.8 & 19.7 & $1.5 \mathrm{zn}$ & yes & $\begin{array}{c}\text { Not yet metallographically } \\
\text { examined (nme) }\end{array}$ \\
\hline $18-3$ & $54-W$ & 64 & 14.8 & 19.7 & $1.5 \mathrm{w}$ & yes & nme \\
\hline $18-4$ & $54-V$ & 64 & 14.8 & 19.7 & $1.5 \mathrm{~V}$ & yes & nme \\
\hline $18-6$ & $54-\operatorname{Re}$ & 64 & 14.8 & 19.7 & $1.5 \mathrm{Re}$ & yes & nme \\
\hline $18-8$ & $21-S$ & 45 & 49.9 & 5 & $.1 \mathrm{~S}$ & yes & nme \\
\hline $18-9$ & $78-N$ & 25 & 45 & 30 & $.1 \mathrm{~N}$ & no & nme \\
\hline $18-10$ & 78-Mo & 24.6 & 44.3 & 29.6 & $1.5 \mathrm{Mo}$ & no & nme \\
\hline $18-11$ & $78-\mathrm{Be}$ & 24.6 & 44.3 & 29.6 & $1.5 \mathrm{Be}$ & yes & nme \\
\hline $18-12$ & 76 & 45 & 25 & 30 & -- & yes & nme \\
\hline $18-13$ & 67 & 45 & 30 & 25 & -- & yes & nme \\
\hline $18-14$ & 66 & 55 & 20 & 25 & -- & yes & nme \\
\hline $18-15$ & 65 & 60 & 15 & 25 & -- & yes & nme \\
\hline $17-5$ & 53 & 70 & 10 & 20 & -- & yes & nme \\
\hline $17-7$ & 52 & 75 & 5 & 20 & -- & no & nme \\
\hline $17-10$ & $50-\mathrm{Al}$ & 7.9 & 75.8 & 14.8 & $1.5 \mathrm{Al}$ & yes & nme \\
\hline $17-11$ & 62 & -- & 80 & 20 & -- & end ${ }^{5}$ & Stressed specimen pitted \\
\hline $17-12$ & 60 & 15 & 65 & 20 & -- & no & Stressed specimen heavily \\
\hline $17-13$ & 58 & 35 & 45 & 20 & -- & no & oxidized \\
\hline $17-15$ & 56 & 55 & 25 & 20 & -- & yes & nme \\
\hline $16-1$ & 33 & 55 & 35 & 10 & -- & yes & Intergranular cracking and \\
\hline $16-2$ & 32 & 65 & 25 & 10 & -- & yes & $\begin{array}{l}\text { uniform oxide } \\
\text { nme }\end{array}$ \\
\hline $16-3$ & $2 I-N$ & 45 & 49.9 & 5 & $.1 \mathrm{~N}$ & yes & nme \\
\hline $16-4$ & 45 & 55 & 30 & 15 & -- & yes & Oxidized entire thickness \\
\hline $16-5$ & 2 & 95 & 5 & -- & -- & yes & $\begin{array}{l}\text { Oxidized heavily on stressed } \\
\text { and unstressed }\end{array}$ \\
\hline
\end{tabular}


Table I. (Continued)

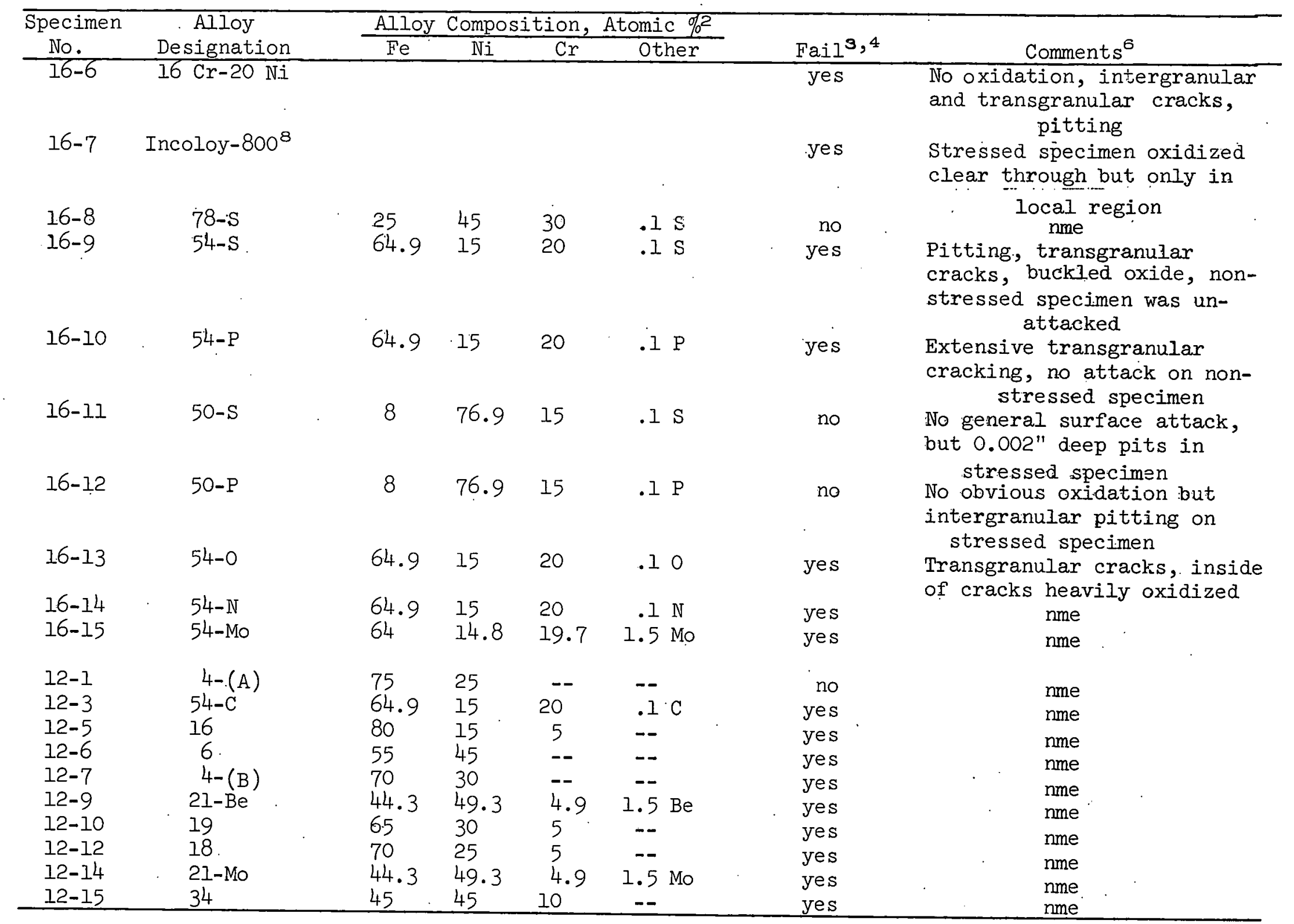


1 This is the uncorrected applied stress and is based on the initial load attached to the specimen divided by specimen area. Not included are corrcctions due to change in shear modulus of spring with temperature, bouyancy of water, torsional stress on wire due to thermal expansion of spring, and creep of specimen.

These are nominal alloy compositions.

3

Some specimens are not reported because fallure occurred at the end rather than the middle area. Failures at the end are believed to result from crevice effects. Specimens metallographically examined in center area but which broke at the end are designated "end:"

4 Failure may result from cracking, pitting, or excessive oxidation.

5 Specimen failed at end, but was examined. Metallography was performed on region from center section.

All specimens are $0.015^{\prime \prime}$ diameter wires. All metallographic examinations are taken from center portion of wire. Specimen is about two inches long.

Furnished by Dr. Allio, Westinǵhouse Reșearch Laboratories.

8. Furnished by Dr. Spalaris, General Electric, Vallecitos. This is a special higher purity. Incoloy-800. 


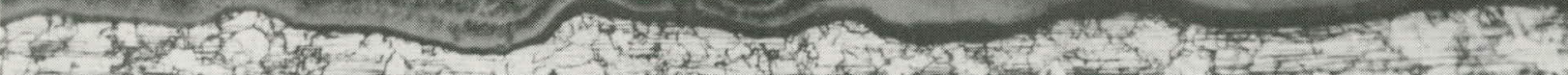

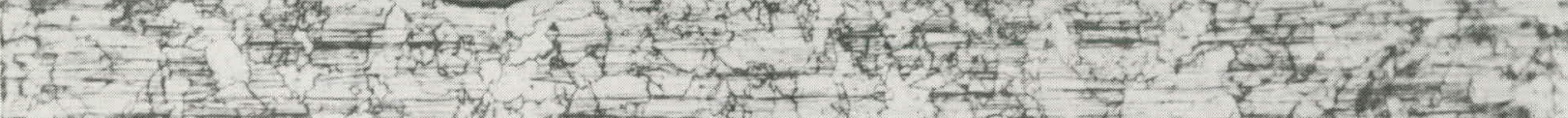

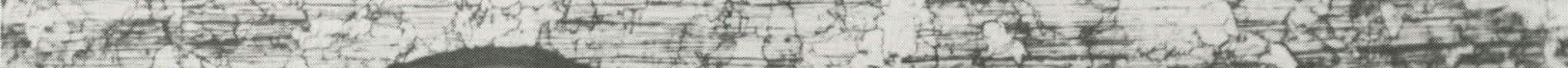
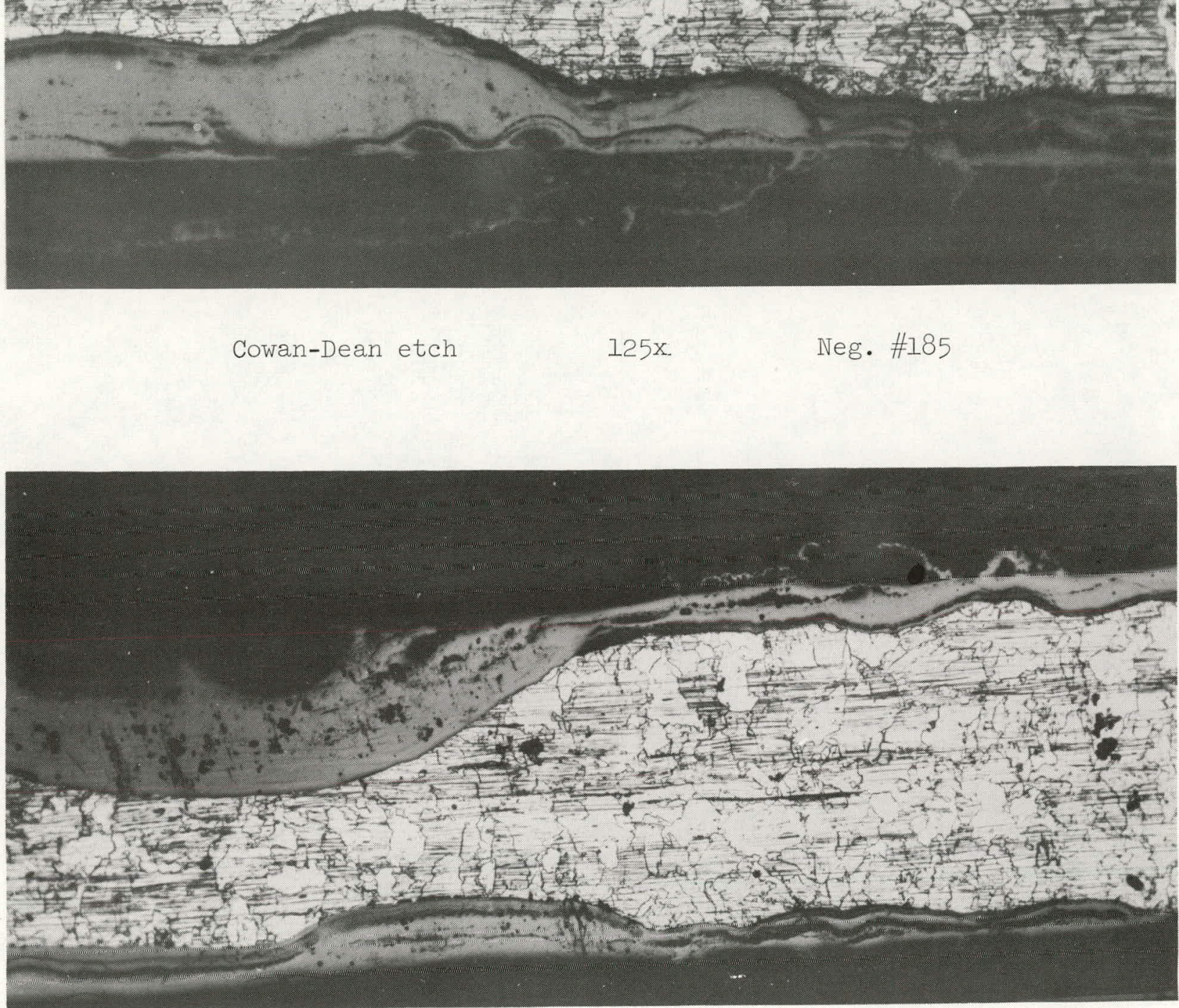

Fig. 1 - Alloy 2 (95 Fe - $5 \mathrm{Ni}$ ) after 24 hours exposure at $600^{\circ} \mathrm{F}$ to water containing $0.1 \mathrm{w} / 0 \mathrm{NaCl}$ and $100 \mathrm{psi}$ oxygen over pressure at ambient. Non-stressed specimen above and stressed specimen below. Initial uncorrected stress applied is

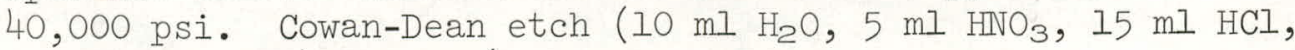
$5 \mathrm{~g} \mathrm{CuSO}_{4}, 30-40 \mathrm{ml} \mathrm{H} \mathrm{H}_{2} \mathrm{O}$ ). 


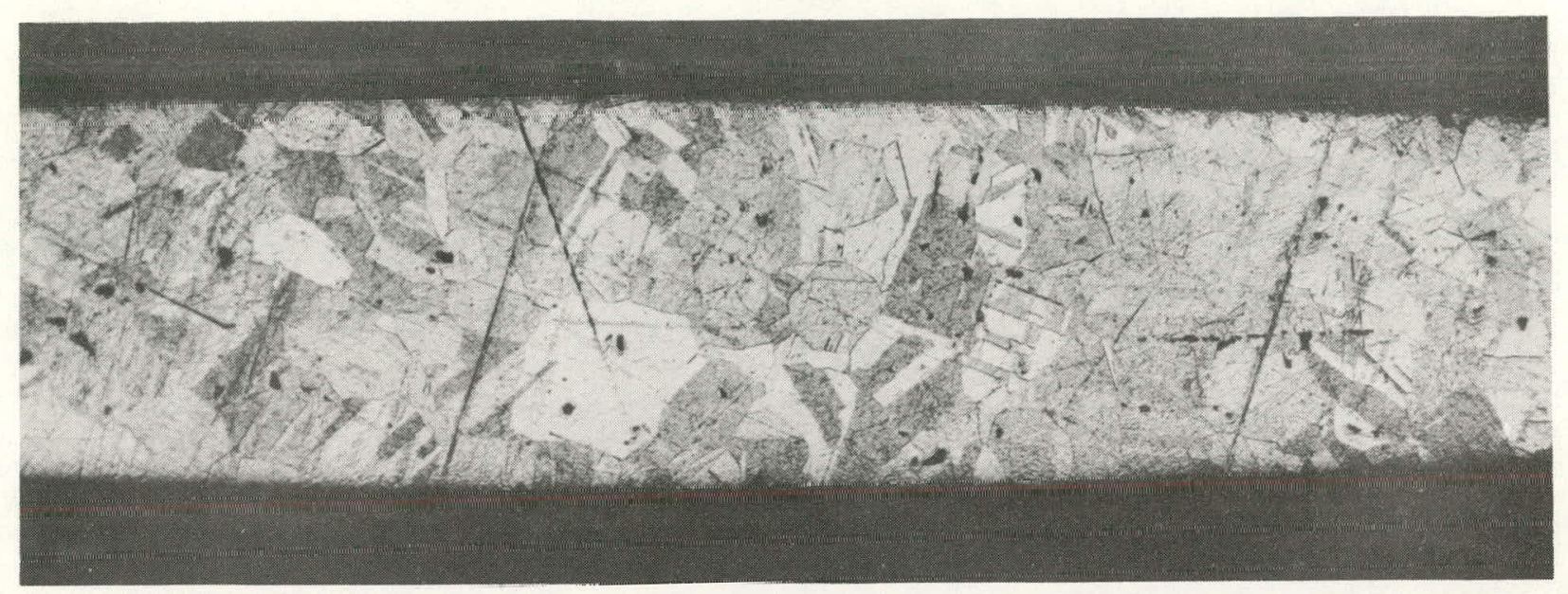
Cowan-Dean etch
$125 x$
Neg. \#197

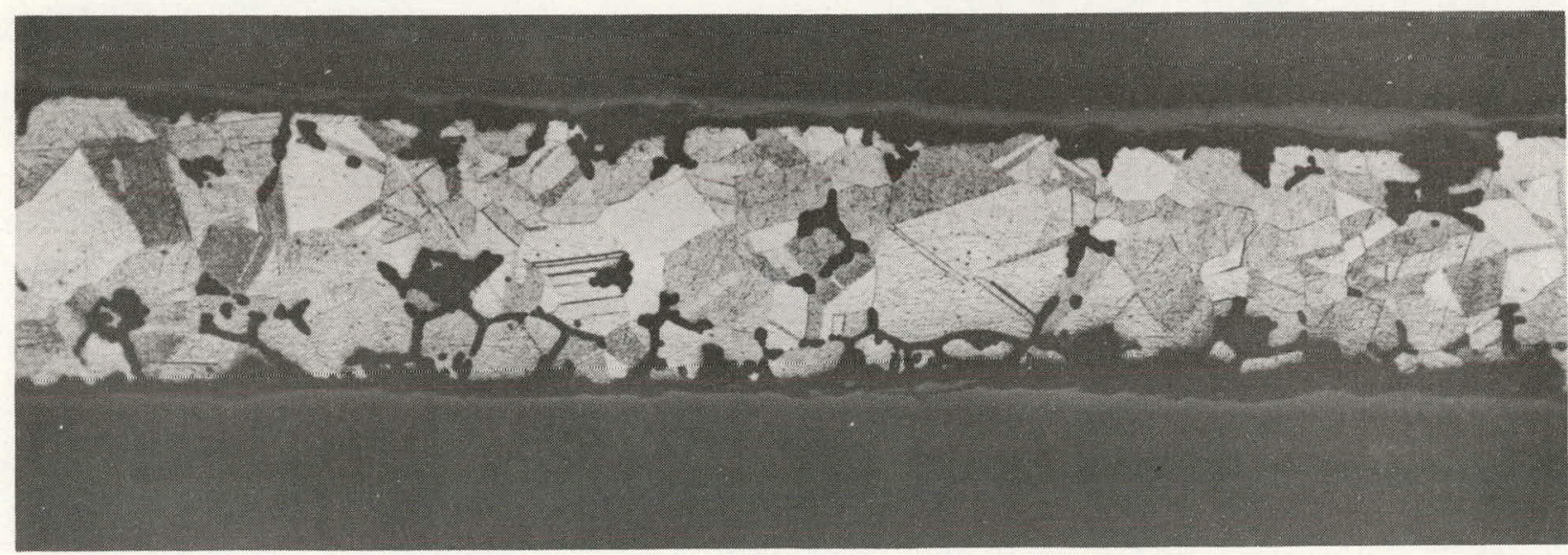

Cowan-Dean etch $\quad$ 125x Neg. \#196

Fig. 2 - Alloy 33 ( $55 \mathrm{Fe}$ - $35 \mathrm{Ni}$ - $10 \mathrm{Cr}$ ) exposed to identical conditions as exposed alloy in Fig. 1. Non-stressed specimen above and stressed below 
Figure 3 shows a special $16 \mathrm{Cr}-20 \mathrm{Ni}$ alloy furnished by Westinghouse Research. This alloy exhibits pitting in both stressed and non-stressed conditions. The stressed specimen exhibits both intergranular and transgranular cracking.

Figure 4 shows alloy 45 (55 Fe-30 Ni-15 Cr). The non-stressed specimen exhibits pits about $0.003 "$ deep. The stressed specimen was oxidized completely through in some cases and in other locations there was intense local oxidation.

Figure 5 shows Incoloy-800 in the stressed and non-stressed conditions. Except for the intense localized oxidation there was no other attack shown in the stressed specimen. There was no observable surface reaction on the non-stressed specimen.

Figure 6 shows alloy 50-P ( 8 Fe-76.9 Ni-15 Cr-0.1 P). The non-stressed specimen shows no obvious surface oxidation or localized attack; the stressed specimen shows pitting plus intergranular attack.

Figure 7 shows alloy 54-P (64.9 Fe-15 Ni-20 Cr-0.1 P). The stressed alloy exhibits heavy transgranular cracking. Two entirely different cracking patterns are observed. One is heavily oxidized inside the crack and the other is not. There is some tightly adherent oxide on the surface of the stressed specimen but none on the non-stressed.

Figure 8 shows alloy 54-S (same as 54-P but 0.1 a/o S). The stressed specimen exhibits transgranular cracking, heavy local pitting-oxidation, and a thin buckled oxide. The non-stressed specimen is not obviously affected.

It is not appropriate at this time to offer much speculation on the significance of the results described above and in the figures. However, several general preliminary observations can be made as follows:

(1) In the absence of stress there is very little oxidation, pitting, or other attack except in the verylow-alloy (alloy 2, for example) materials.

(2) The presence of stress promotes oxidation, cracking, and pitting, the extent of each depending greatly on the alloy. Reasons for such phenomena are generally apparent (i.e., breakdown of local passive conditions) but elucidation of the details of the process require further work.

(3) Cracking can be both intergranular and transgranular in this alloy system.

(4) The environmental coriditions are generally severe and the uncorrected 40,000 psi applied stress is generally above the yield. See Table II in Section III for room temperature mechanical properties. 


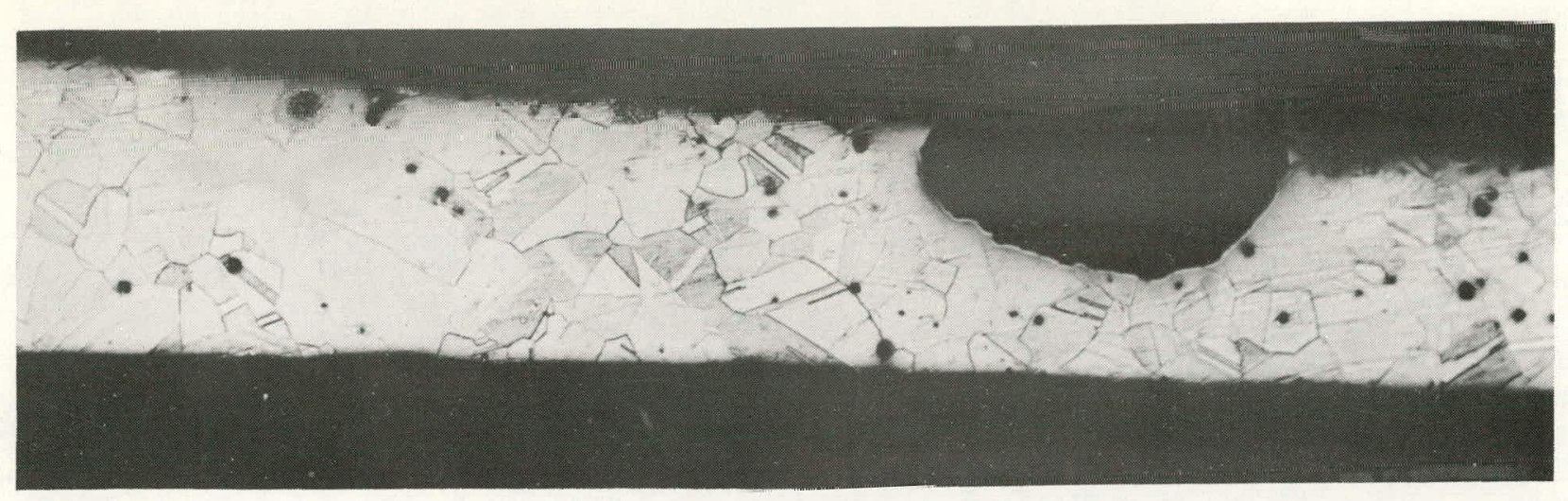

Cowan-Dean etch 125x Neg. \#205

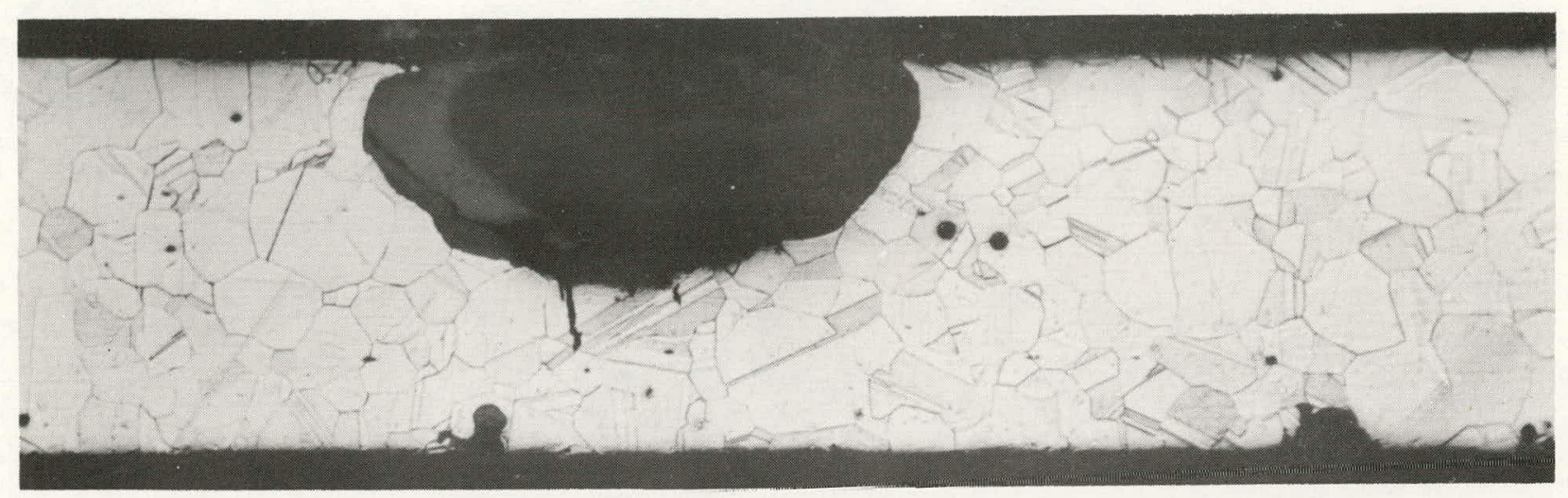

Cowan-Dean etch 125x Neg. \#203

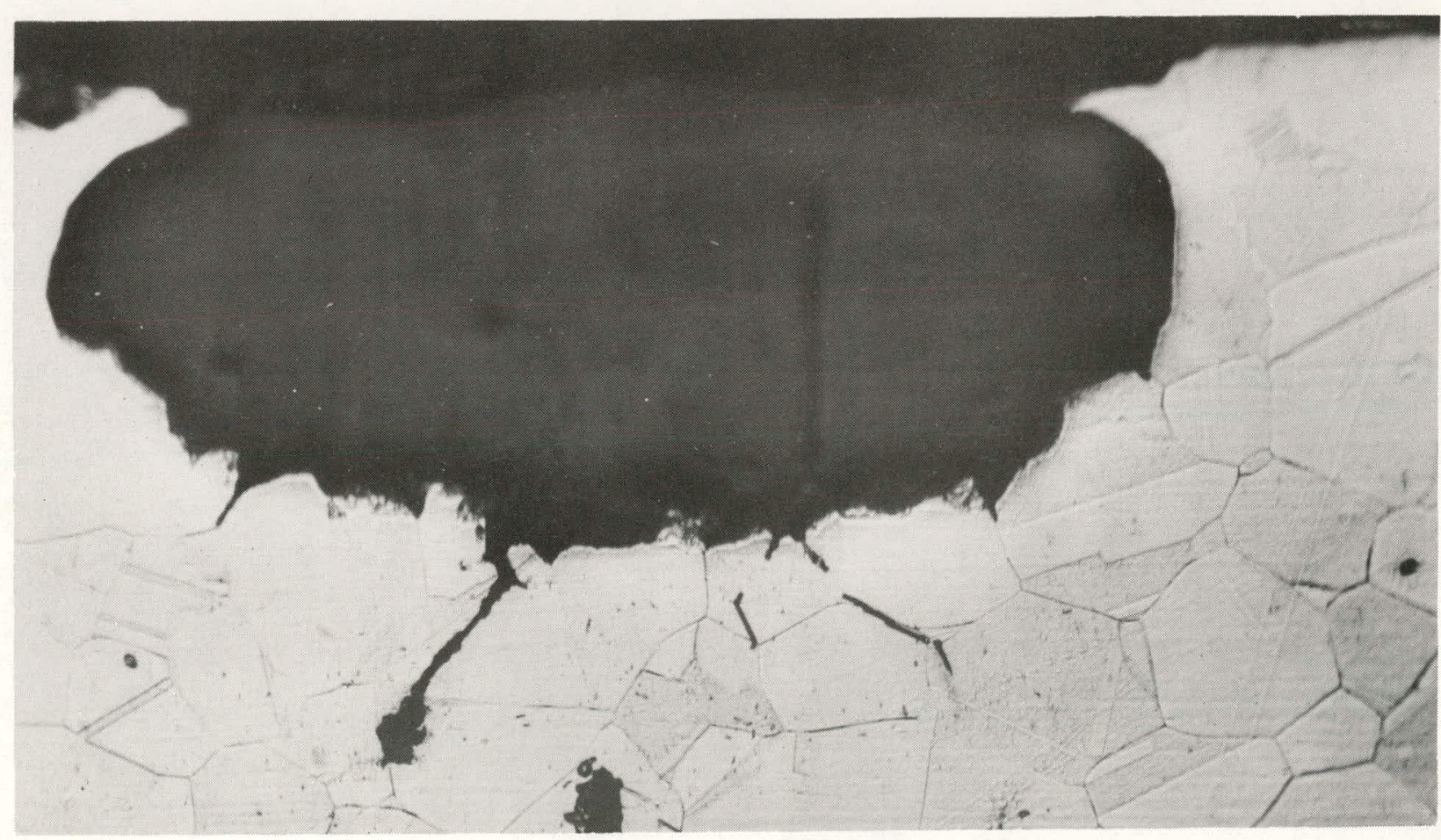

Cowan-Dean etch 350x Neg. \#204

Fig. 3 - Special $16 \mathrm{Cr}$ - $20 \mathrm{Ni}$ - Bal Fe alloy exposed to conditions identical to those in Fig. 1. Top photo is non-stressed, middle is stressed, and bottom is detail of another area in stressed specimen. 


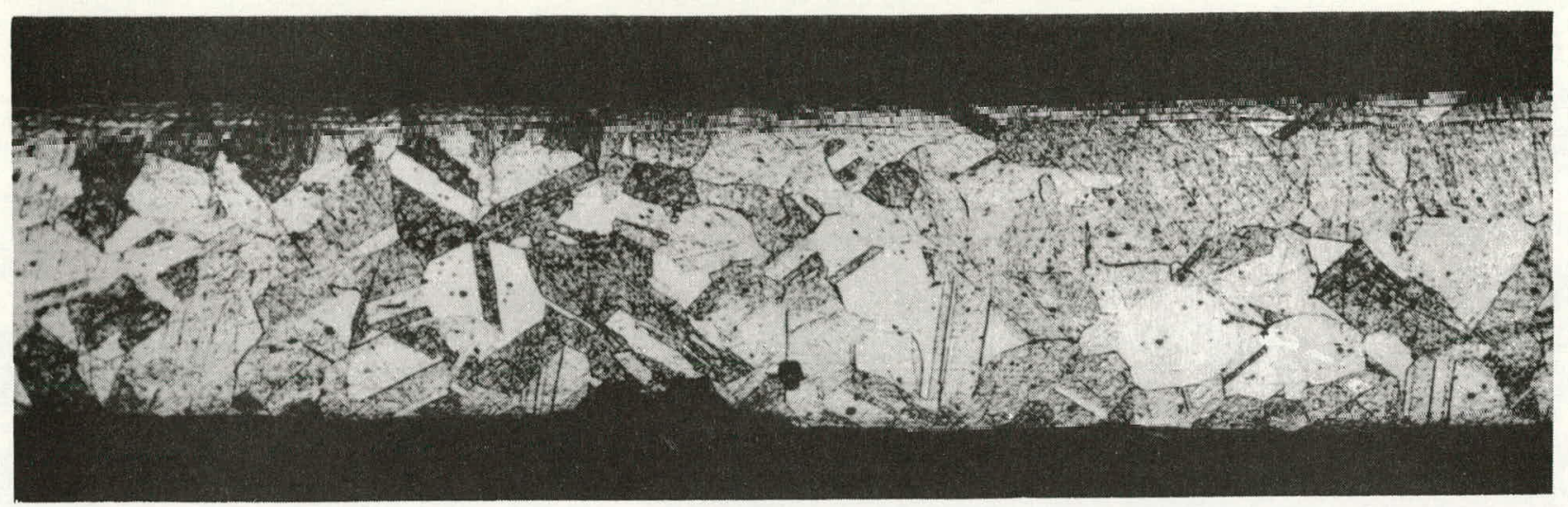

Cowan-Dean etch 125x Neg. \#191

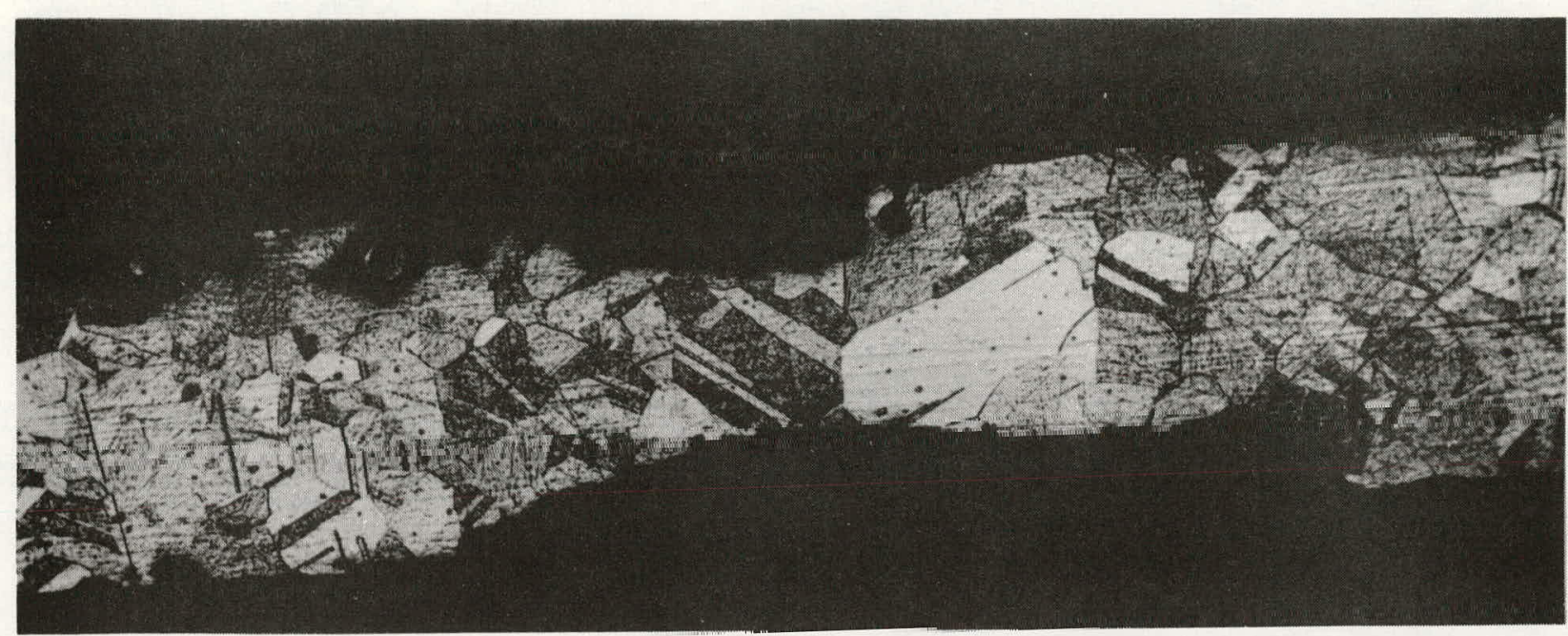

Cowan-Dean etch 125x Neg. \#192

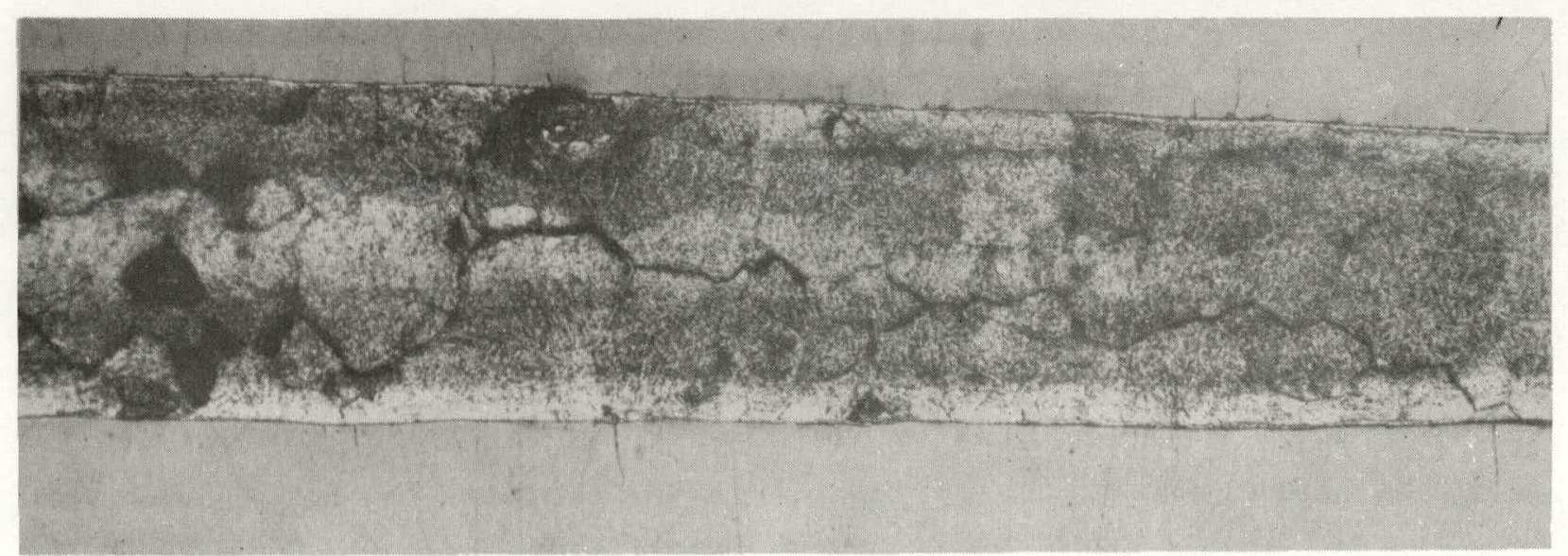

Cowan-Dean etch 125x Neg. \#193

Fig. 4 - Alloy 45 (55 Fe - $30 \mathrm{Ni}$ - $15 \mathrm{Cr}$ ) exposed to conditions identical to those in Fig. 1. Top is non-stressed, middle is one area of stressed, and bottom is another area of stressed. Section in bottom photo is completely oxidized. 


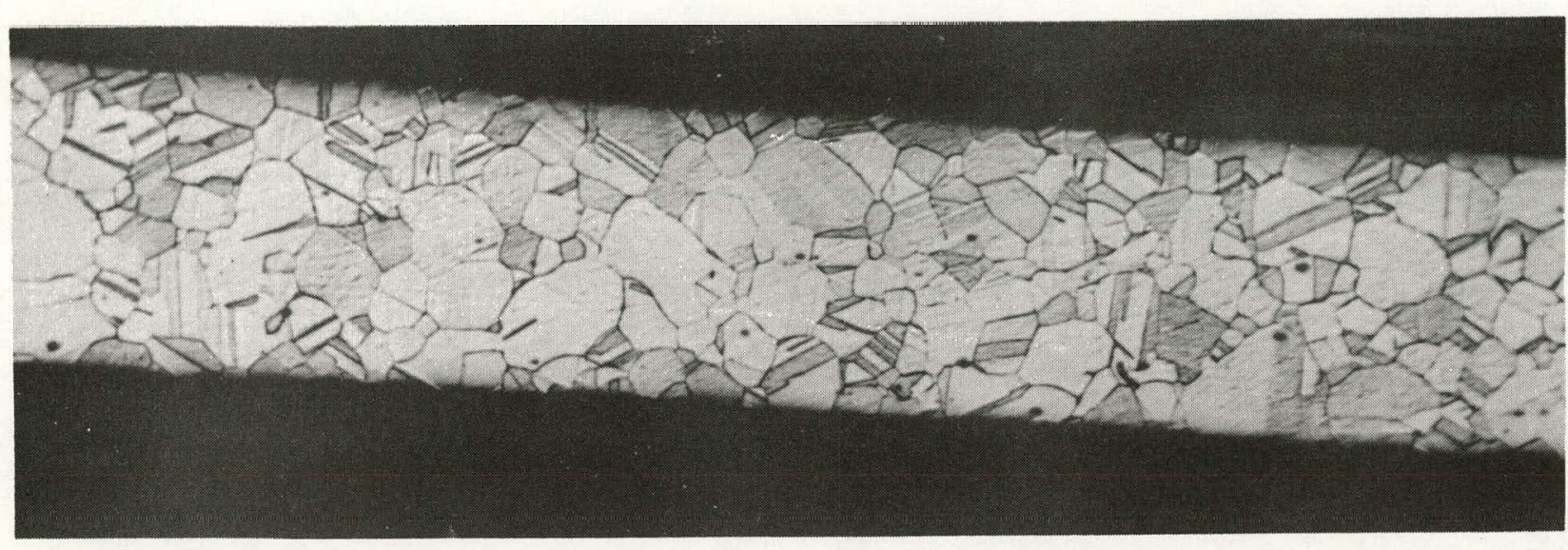

\section{Cowan-Dean etch 125x Neg. \#207}

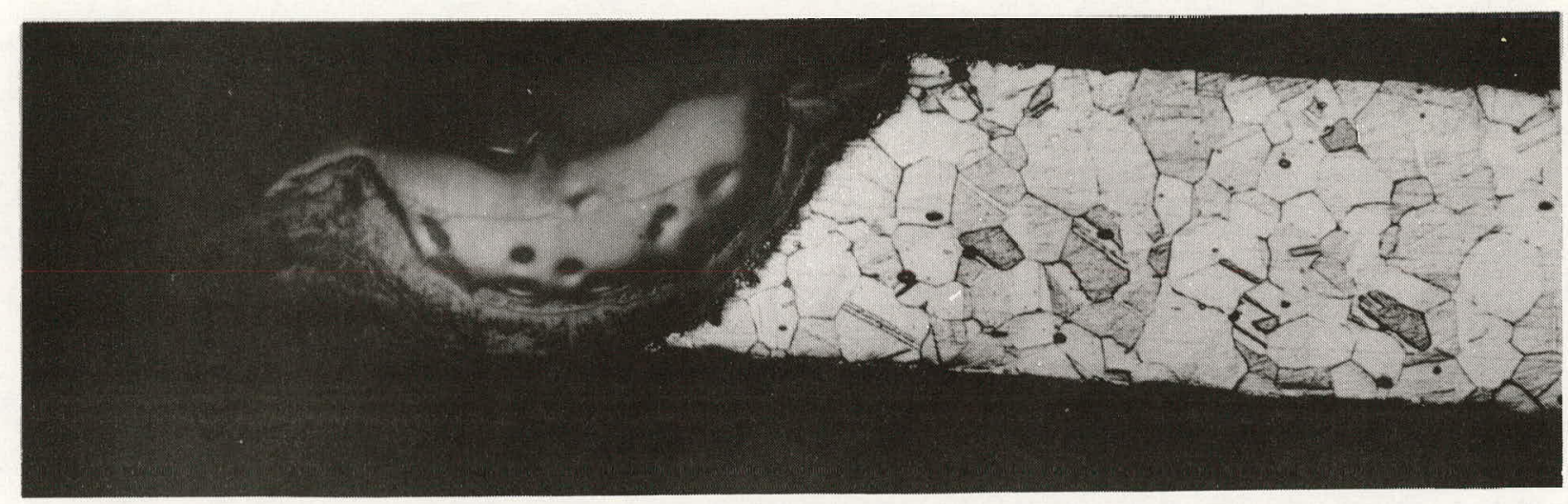

Cowan-Dean etch $125 \mathrm{x} \quad$ Neg. \#206

Fig. 5 - Incoloy-800 specially prepared to have low impurities. Exposed to conditions identical to those for Fig. 1. Top specimen is non-stressed, bottom is stressed. 


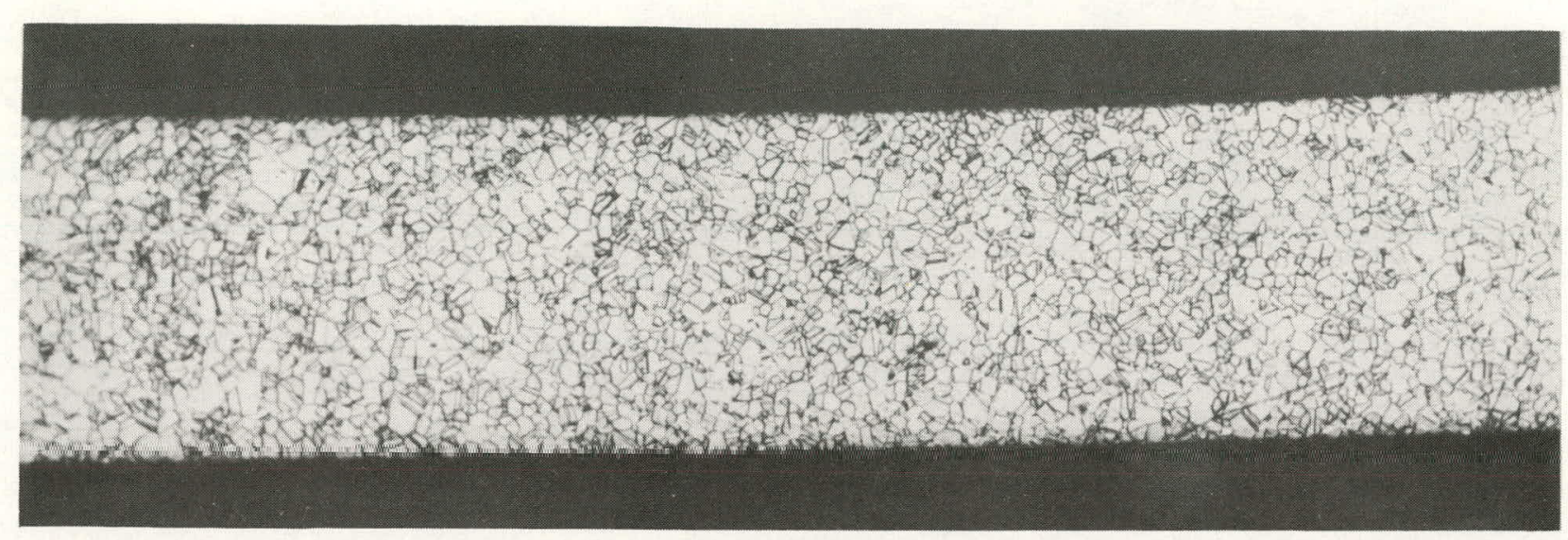

Cowan-Dean etch 125x Neg. \#198

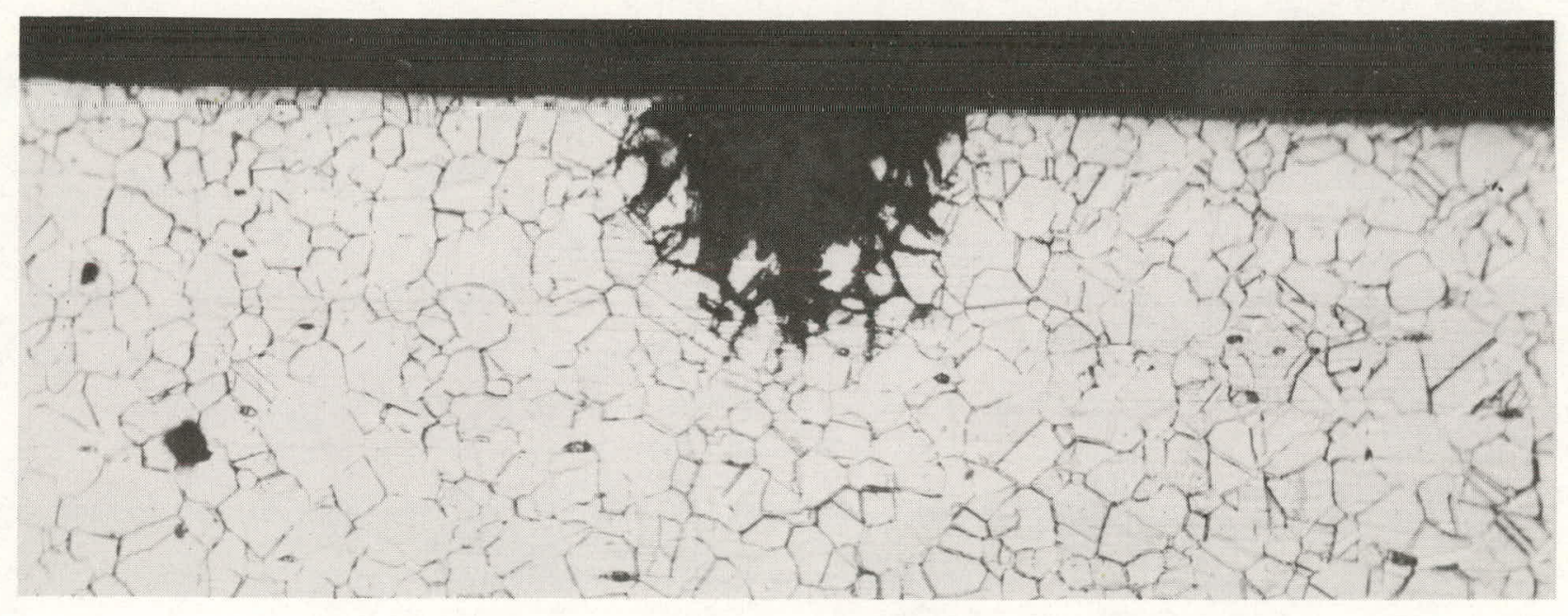

Cowan-Dean etch 250x Neg. \#199

Fig. 6 - Alloy 50-P (8 Fe - $76.9 \mathrm{Ni}$ - $15 \mathrm{Cr}$ - $0.1 \mathrm{P}$ ) exposed to conditions identical to those in Fig. 1. Top specimen is non-stressed, bottom is stressed. 


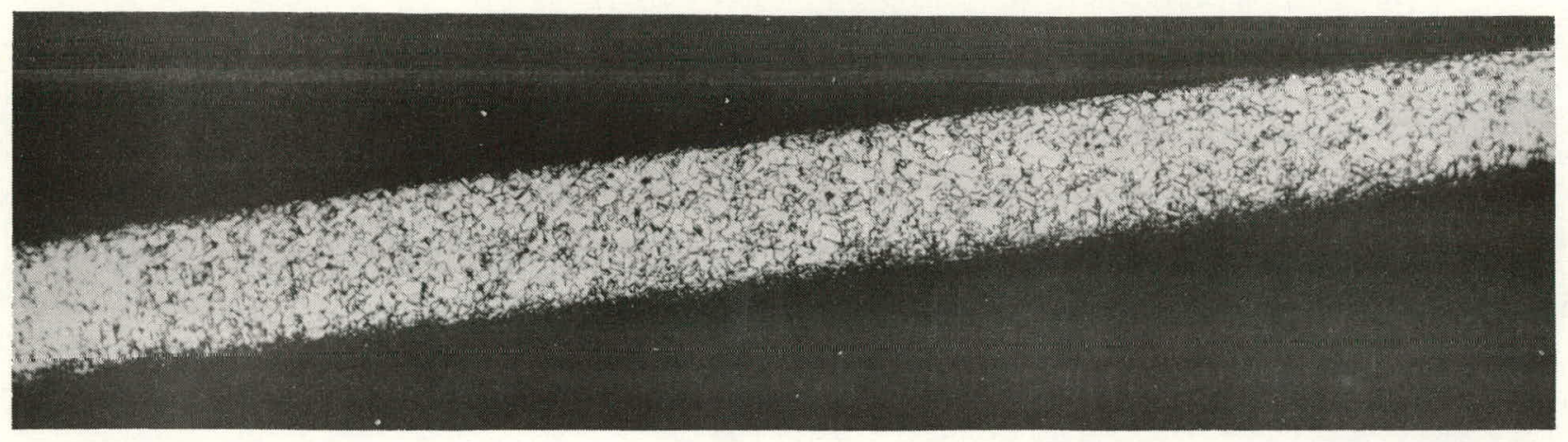

Cowan-Dean etch 125x Neg. \#190

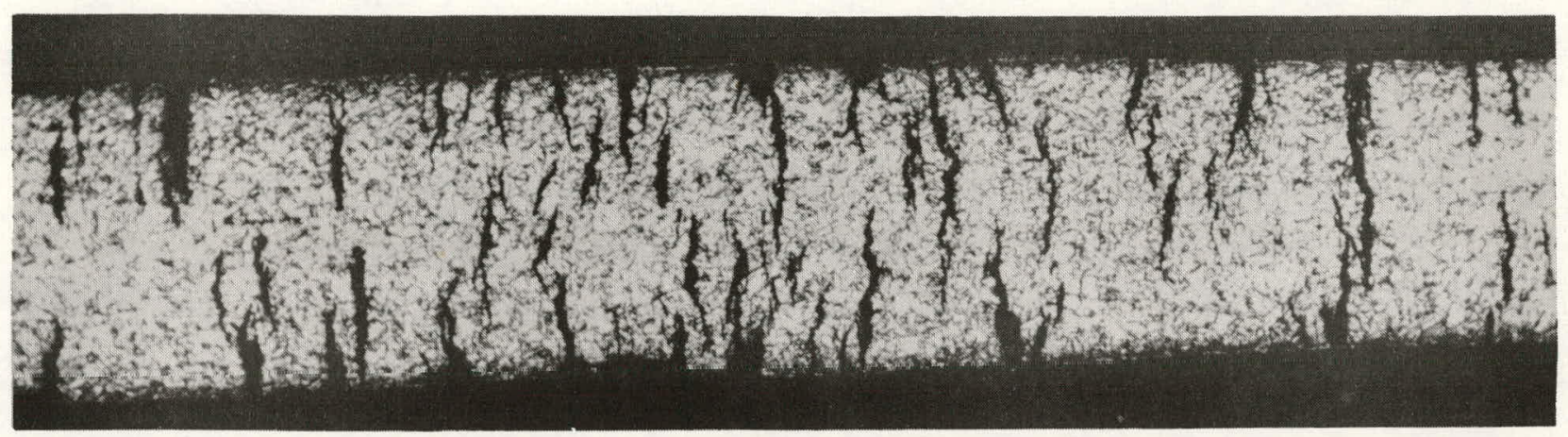

Cowan-Dean etch $125 \mathrm{x} \quad$ Neg. \#189

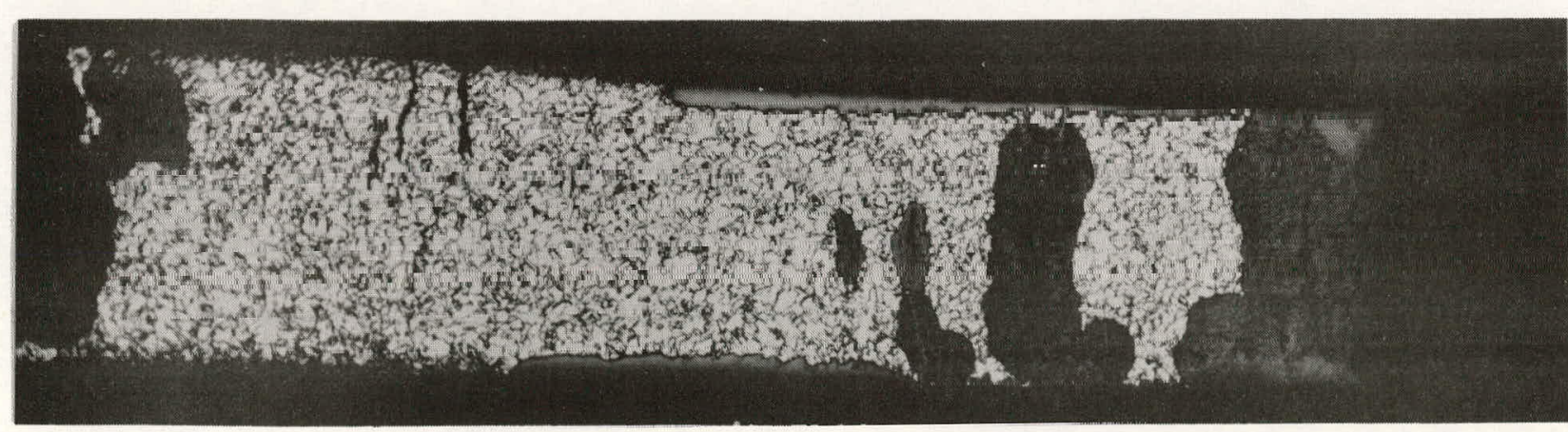

Cowan-Dean etch $125 \mathrm{x}$ Neg. \#188

Fig. 7 - Alloy 54-P (64.9 Fe - $15 \mathrm{Ni}$ - $20 \mathrm{Cr}$ - $0.1 \mathrm{P})$ exposed to same conditions as Fig. 1. Top specimen is non-stressed and bottom two are stressed but from different locations. 


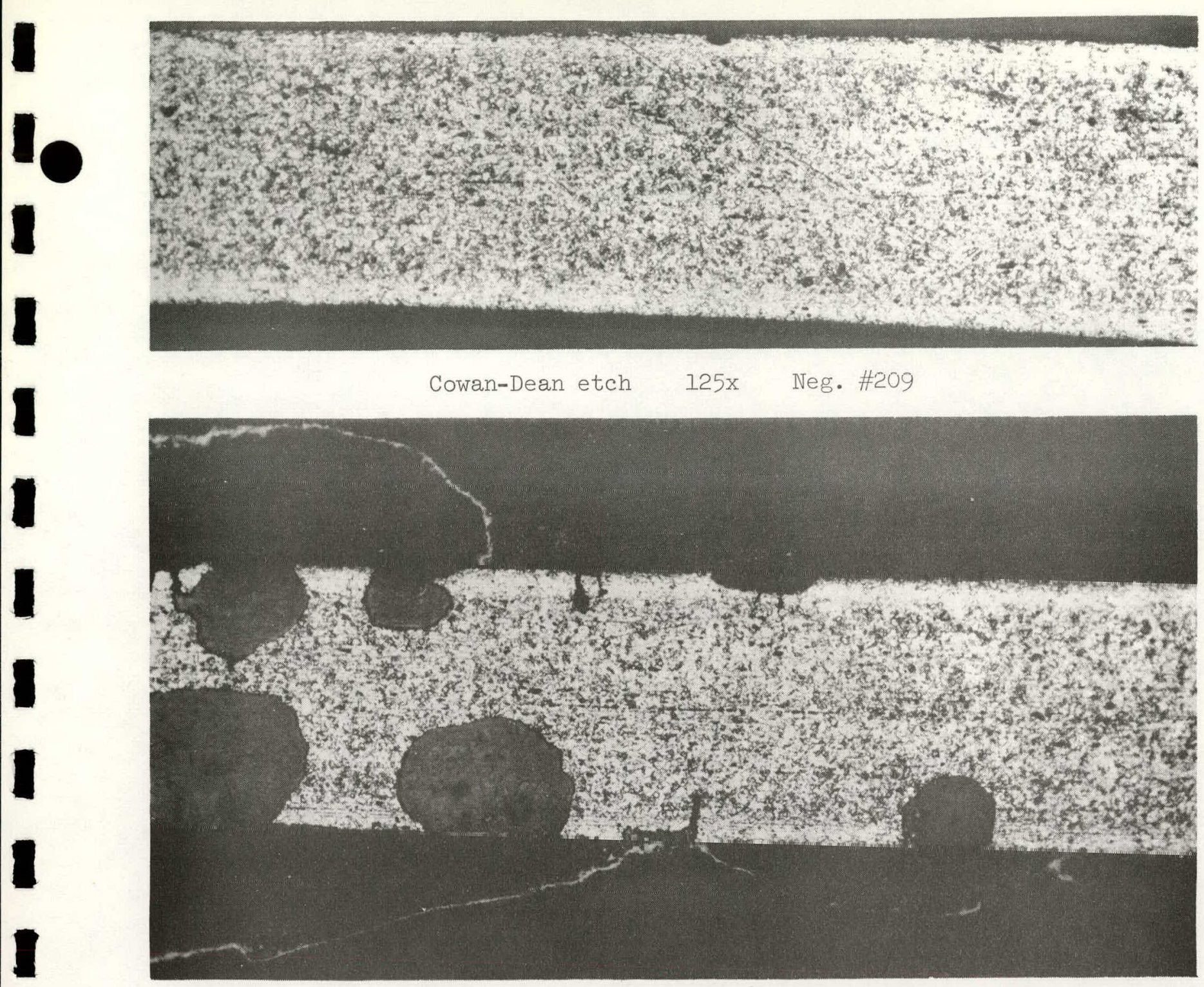

Cowan-Dean etch 125x Neg. \#184

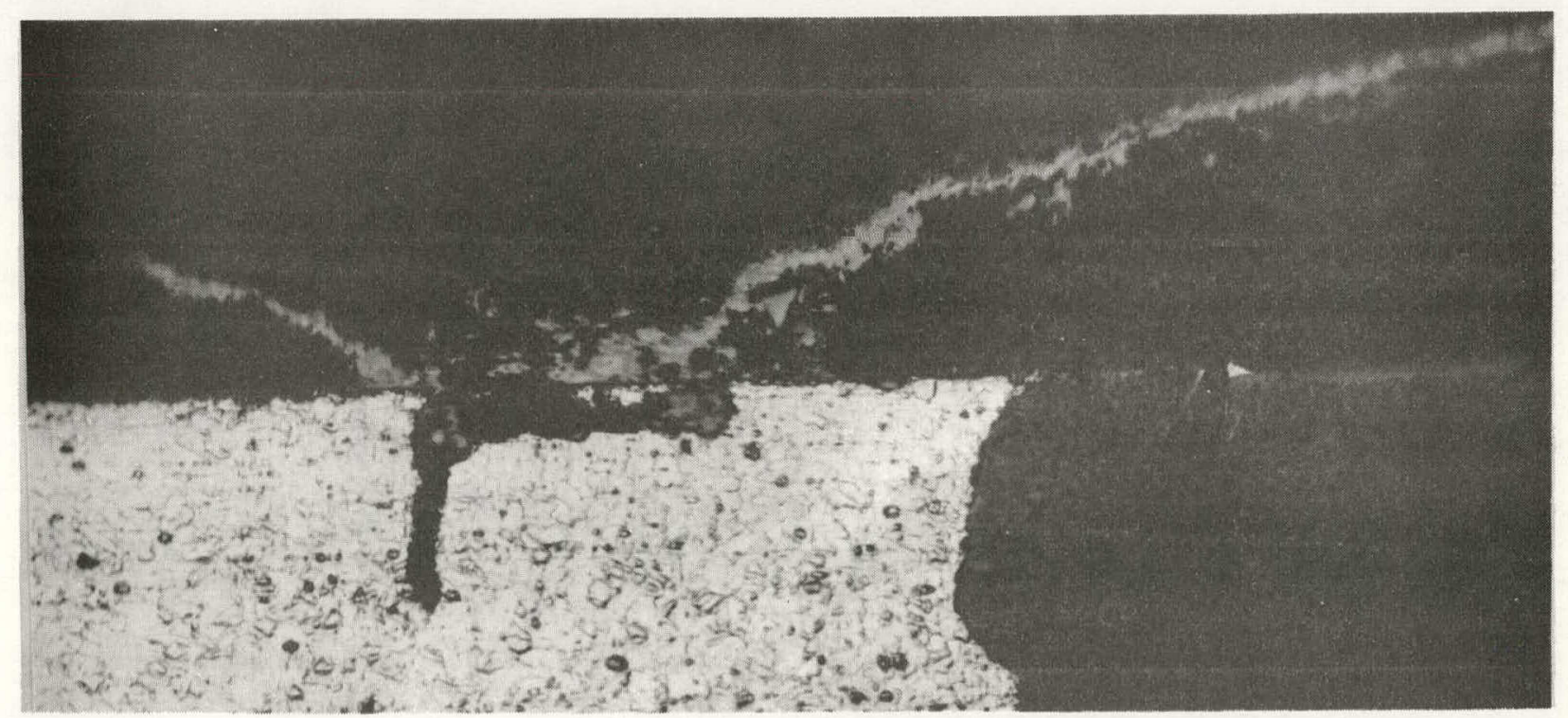

Cowan-Dean etch 350x Neg. \#183

Fig. 8 - Alloy 54-S (64.9 Fe - $15 \mathrm{Ni}$ - $20 \mathrm{Cr}$ - $0.1 \mathrm{~S}$ ) exposed to conditions identical to those in Fig. 1. Top photo is non-stressed, middle is stressed, bottom is stressed. 


\section{SCOPING STUDIES OF ENVIRONMENTAL EFFECTS}

The results described in the previous section raise numerous questions - one of the most important relating to the role of the environment. To this end scoping studies have been initiated in which a series of alloys is being systematically exposed to various components of the water-oxygen-chloride environment (i.e., water, water-oxygen, waterchloride, oxygen). As of the date of this report, the water environment study has been completed. Following this, the water-oxygen, waterchloride, water-hydrogen, water-chloride-oxygen, and other environments will be used, as appropriate.

In the water test, double-distilled water was used; the autoclave was filled to the top and the test assembly inserted; the autoclave was then degassed by heating to $220^{\circ} \mathrm{F}$ leaving the top valve open; the top valve was then closed and temperature increased to $600^{\circ} \mathrm{F}$; the test duration was 24 hours.

In general there was very little attack on the stressed specimens in the water environment. A comparison between stressed and non-stressed alloys is shown in Figs. 9 and 11. Figure 10 shows alloy 60 ( 15 Fe-65 Ni$20 \mathrm{Cr}$ ) in water and water-oxygen-chloride environments, both specimens at $40,000 \mathrm{psi}$. Figure 10 shows the same comparison for alloy 62 (80 Ni$20 \mathrm{Cr})$. From a comparison of Figs. 10 and 11 with Figs. 2-9 it appears that more than the stress is required for the accelerated pitting and oxidation phenomena. The environment appears to play an important part. Additional experiments and additional metallography are underway and should illuminate further the nature of environmental differences.

\section{MECHANICAL PROPERTIES}

In order for the stress-corrosion cracking experiments to be conducted at some stress relative to the mechanical capability of a given material, it is necessary to determine the tensile properties of all compositions as a function of temperature.

Tensile properties of the various alloys at room temperature are summarized in Table II. There is little comment appropriate at this time. Work is continuing to extend these data.to higher temperatures. Some work will also be done to determine the effects of annealing time and grain size.

It is planned generaliy to obtain the tensile properties on all alloys from room temperature to $1200^{\circ} \mathrm{F}$, at $200^{\circ} \mathrm{F}$ increments. The stress-corrosion experiments will be stressed at some fractional value of the yield strength and comparison from alloy to alloy will be made on the basis of yield point fraction. 
Table II. Room Temperature Tensile Results $2,3,4$

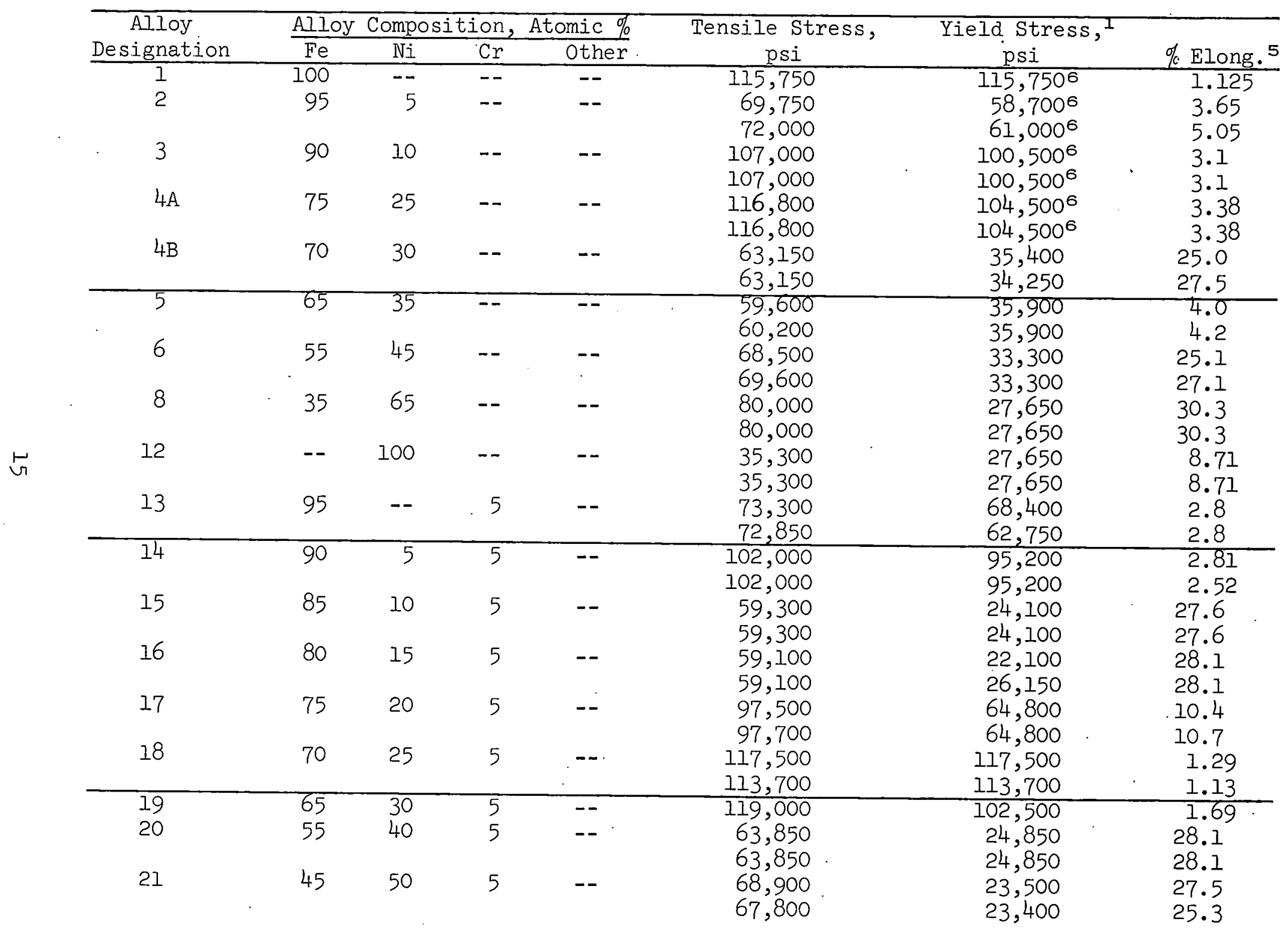


Table II. (Continued)

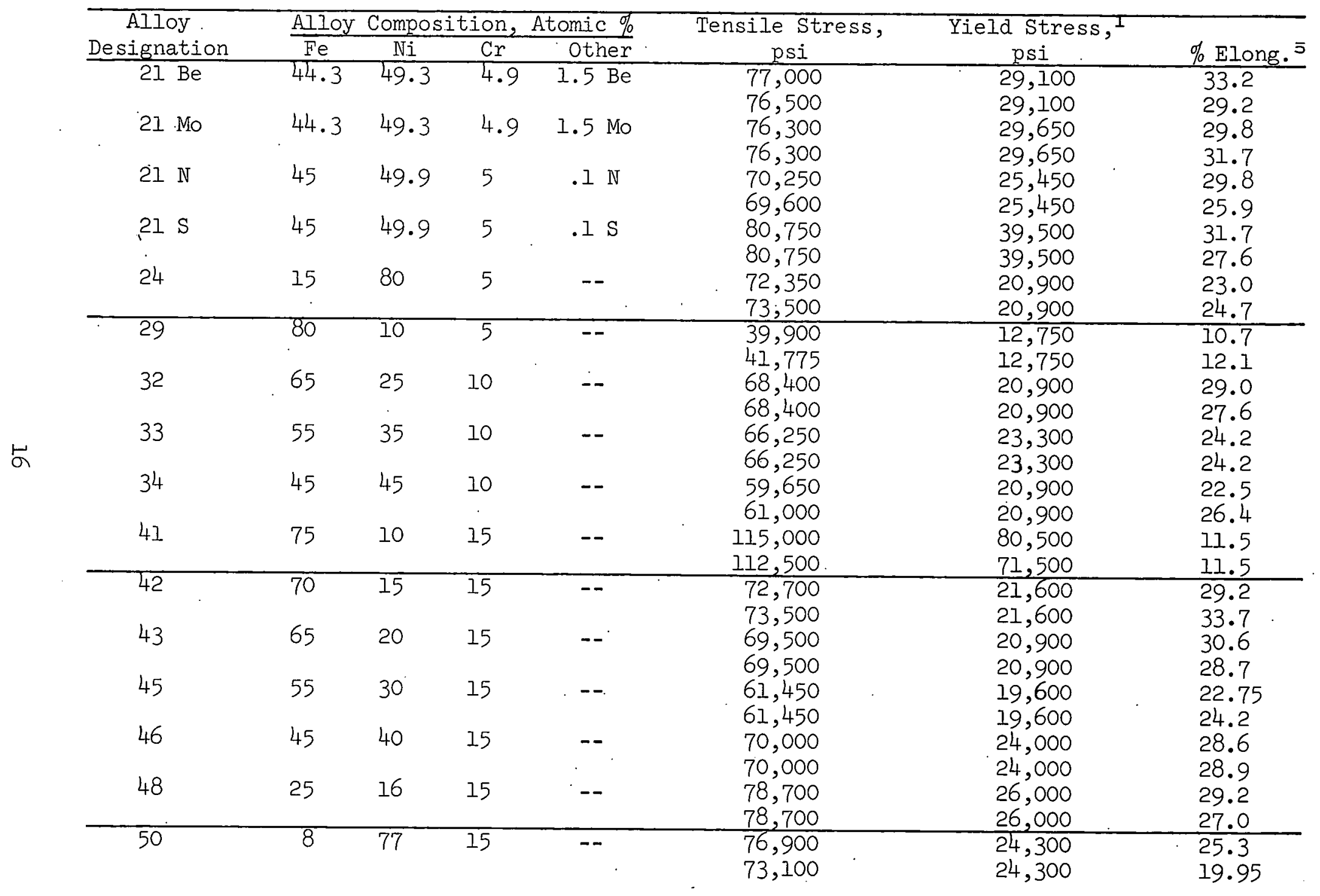


Table II. (Continued)

\begin{tabular}{|c|c|c|c|c|c|c|c|}
\hline $\begin{array}{c}\text { Alloy } \\
\text { Designation }\end{array}$ & $\frac{\text { Alloy }}{\text { Fe }}$ & $\frac{\text { Compos }}{\mathrm{Ni}}$ & $\frac{\mathrm{tion},}{\mathrm{Cr}}$ & $\frac{\text { Atomic \% }}{\text { Other }}$ & $\begin{array}{c}\text { Tensile stress, } \\
\text { psi }\end{array}$ & $\begin{array}{c}\text { Yield Stress, } \\
\text { psi }\end{array}$ & $\%$ Elong. 5 \\
\hline $50 \mathrm{Al}$ & 7.9 & 75.8 & 14.8 & $1.5 \mathrm{Al}$ & 125,800 & 102,000 & 3.54 \\
\hline & & & & & 125,800 & 102,000 & 3.54 \\
\hline $50 \mathrm{Be}$ & 7.9 & 75.8 & 14.8 & $1.5 \mathrm{Be}$ & 85,500 & 31,600 & 26.9 \\
\hline $50 \mathrm{Mo}$ & 7.9 & 75.8 & 748 & $75 \mathrm{M}$ & 85,350 & 31,600 & 27.5 \\
\hline & & 13.0 & 14.0 & 1.) 1 MO & $\begin{array}{l}90,500 \\
90,500\end{array}$ & $\begin{array}{l}31,600 \\
31,600\end{array}$ & $\begin{array}{l}27.0 \\
27.0\end{array}$ \\
\hline $50 \mathrm{P}$ & 8 & 76.9 & 15 & $.1 \mathrm{P}$ & 94,600 & 39,500 & 32.6 \\
\hline & & & & & 94,600 & 40,700 & 30.3 \\
\hline $50 \mathrm{~S}$ & 8 & 76.9 & 15 & $.1 \mathrm{~S}$ & 83,600 & 48,000 & 12.38 \\
\hline & & & & & 82,500 & 48,000 & 11.5 \\
\hline $50 \mathrm{Ti}$ & 7.9 & 75.8 & 14.8 & $1.5 \mathrm{Ti}$ & 81,400 & 31,650 & 18.5 \\
\hline & & & & & 78,750 & 31,100 & 18.5 \\
\hline 52 & 75 & 5 & 20 & $\therefore$ & 81,900 & 25,850 & 26.5 \\
\hline $52 \mathrm{R}$ & 61 & & & & 81,900 & 25,850 & 26.5 \\
\hline sc Be & 04 & 14.8 & 19.7 & $1.5 \mathrm{Be}$ & 119,500 & 65,800 & $25 \cdot 3$ \\
\hline 53 & 70 & 70 & ?० & & 121,200 & 65,800 & 28.0 \\
\hline 54 & 65 & 15 & 50 & -- & 72,750 & 25,700 & 41.4 \\
\hline & & & & - & $\begin{array}{l}76,800 \\
76,800\end{array}$ & $\begin{array}{l}24,300 \\
24,300\end{array}$ & 41.0 \\
\hline $54 \mathrm{Al}$ & 64 & 14.8 & 19.7 & $1.5 \mathrm{Al}$ & 79,500 & $\frac{4+, 500}{28,250}$ & $\frac{43.5}{33.2}$ \\
\hline $54 \mathrm{Au}$ & 64 & 14.8 & 19.7 & $1.5 \mathrm{Au}$ & 86,600 & 40,400 & 38.8 \\
\hline & & & & & 85,900 & 40,400 & 37.8 \\
\hline $5.4 \mathrm{Be}$ & 64 & 14.8 & 19.7 & $1.5 \mathrm{Be}$ & 77,700 & 28,250 & 33.2 \\
\hline & & & & & 77,700 & 28,250 & 33.2 \\
\hline $54 \mathrm{C}$ & 64.9 & 15 & 20 & $.1 \mathrm{C}$ & 76,000 & 27,650 & 36.0 \\
\hline & & & & & 76,300 & 27,650 & 41.8 \\
\hline $54 \mathrm{Co}$ & 64 & 14.8 & 19.7 & $1.5 \mathrm{Co}$ & 78,000 & 26,000 & 40.4 \\
\hline $54 \mathrm{Cu}$ & 64 & 7) 8 & 197 & 1 $5 \mathrm{C}$ & 79,400 & $\frac{26,000}{27,20}$ & $\frac{40.4}{28.7}$ \\
\hline & 04 & 14.0 & 19.7 & $1.5 \mathrm{Cl}$ & $\begin{array}{l}78,000 \\
75,200\end{array}$ & $\begin{array}{l}37,600 \\
37,600\end{array}$ & $\begin{array}{l}28.1 \\
24.1\end{array}$ \\
\hline $54 \mathrm{Ir}$ & 64 & 14.8 & 19.7 & $1.5 \mathrm{Ir}$ & 83,800 & 33,300 & 43.0 \\
\hline & & & & & 83,800 & 33,300 & 43.0 \\
\hline
\end{tabular}


Table II. (Continued)

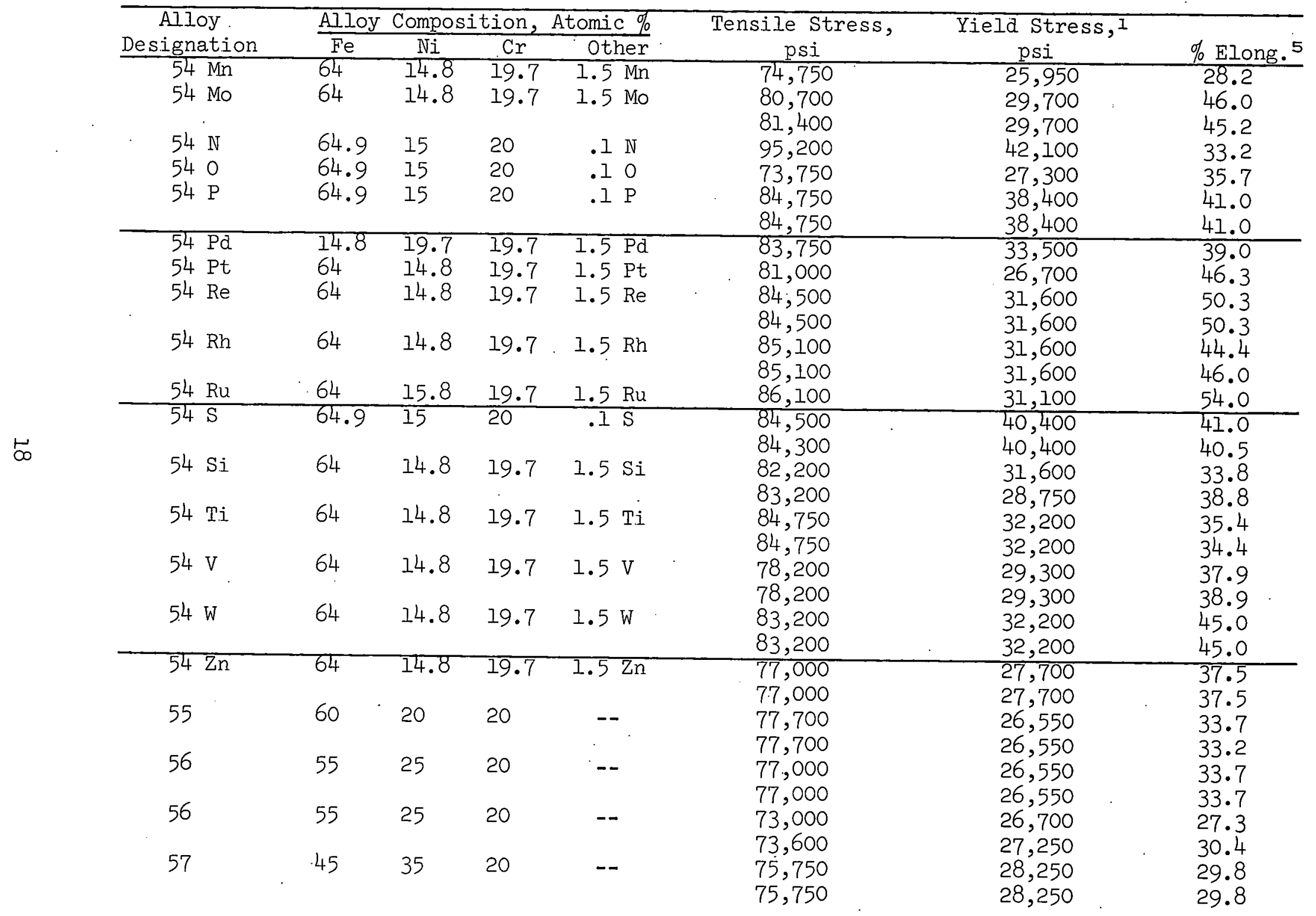


Table II. (Continued)

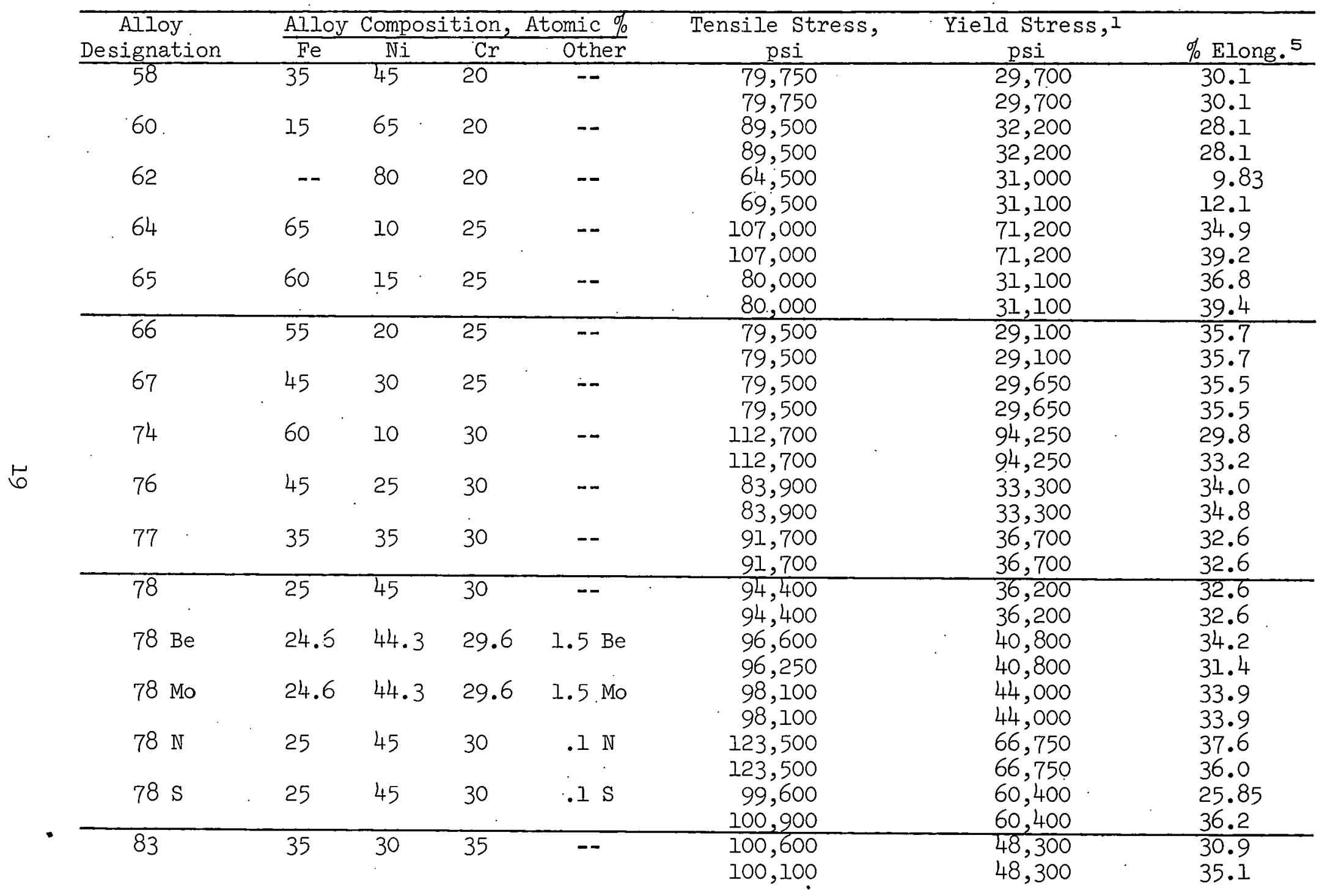


Table II. (Continued)

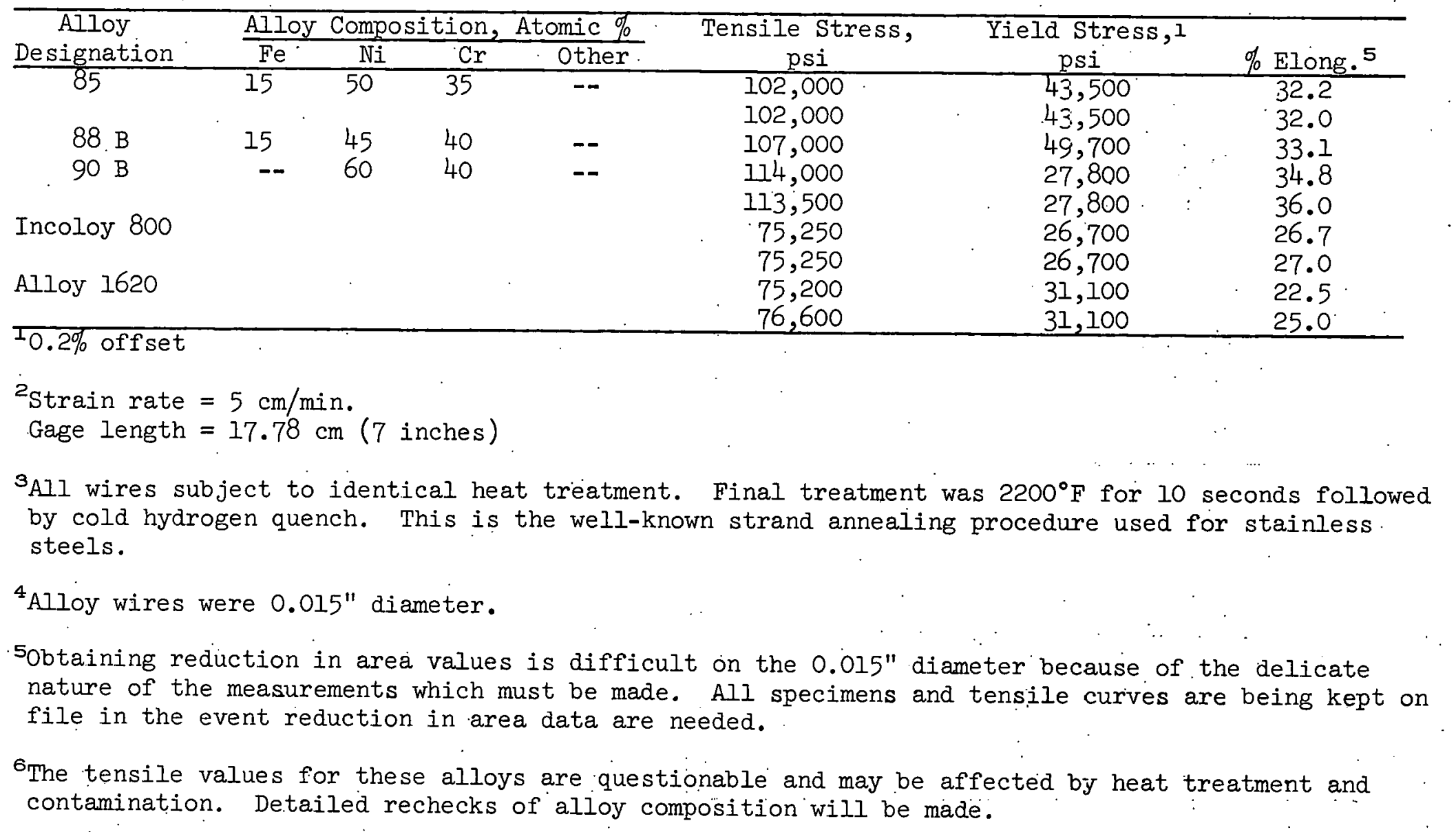




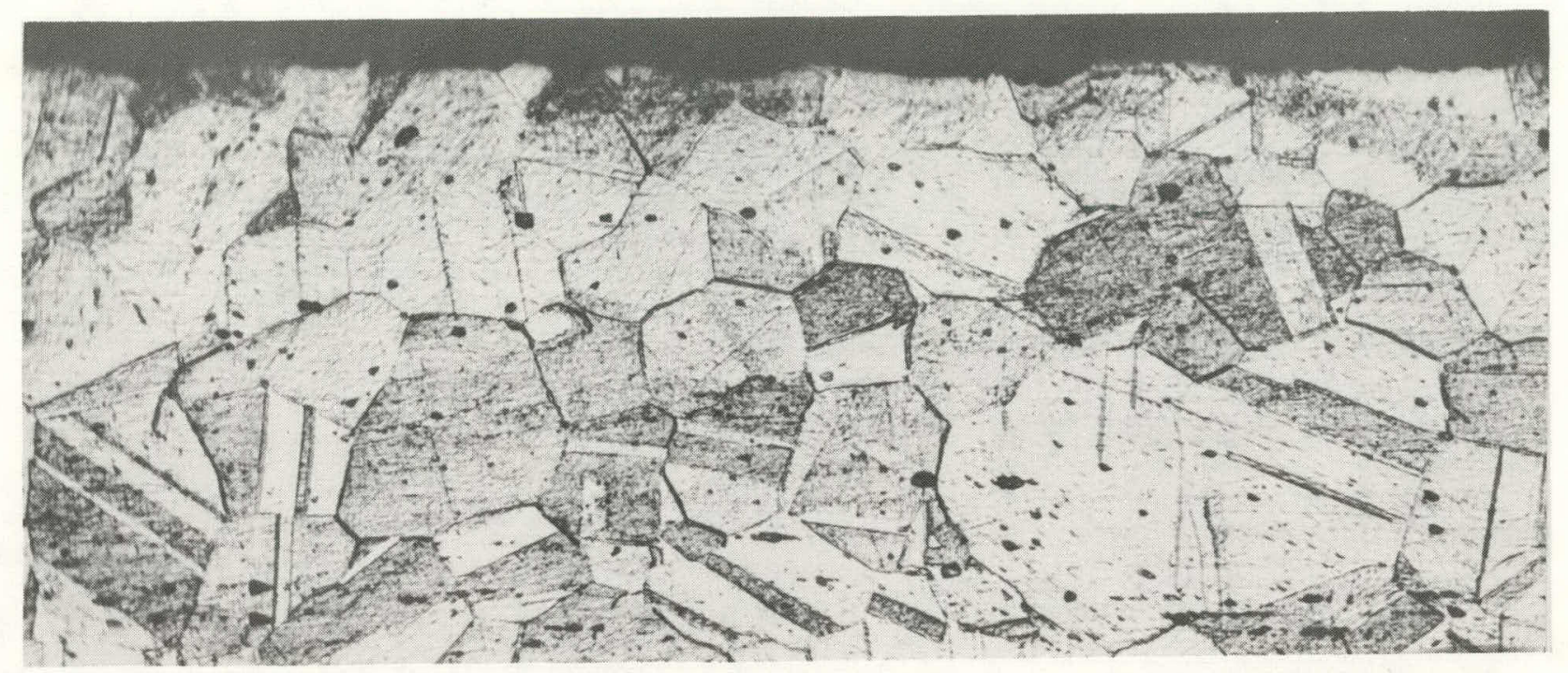

Cowan-Dean etch 350x Neg. \#222

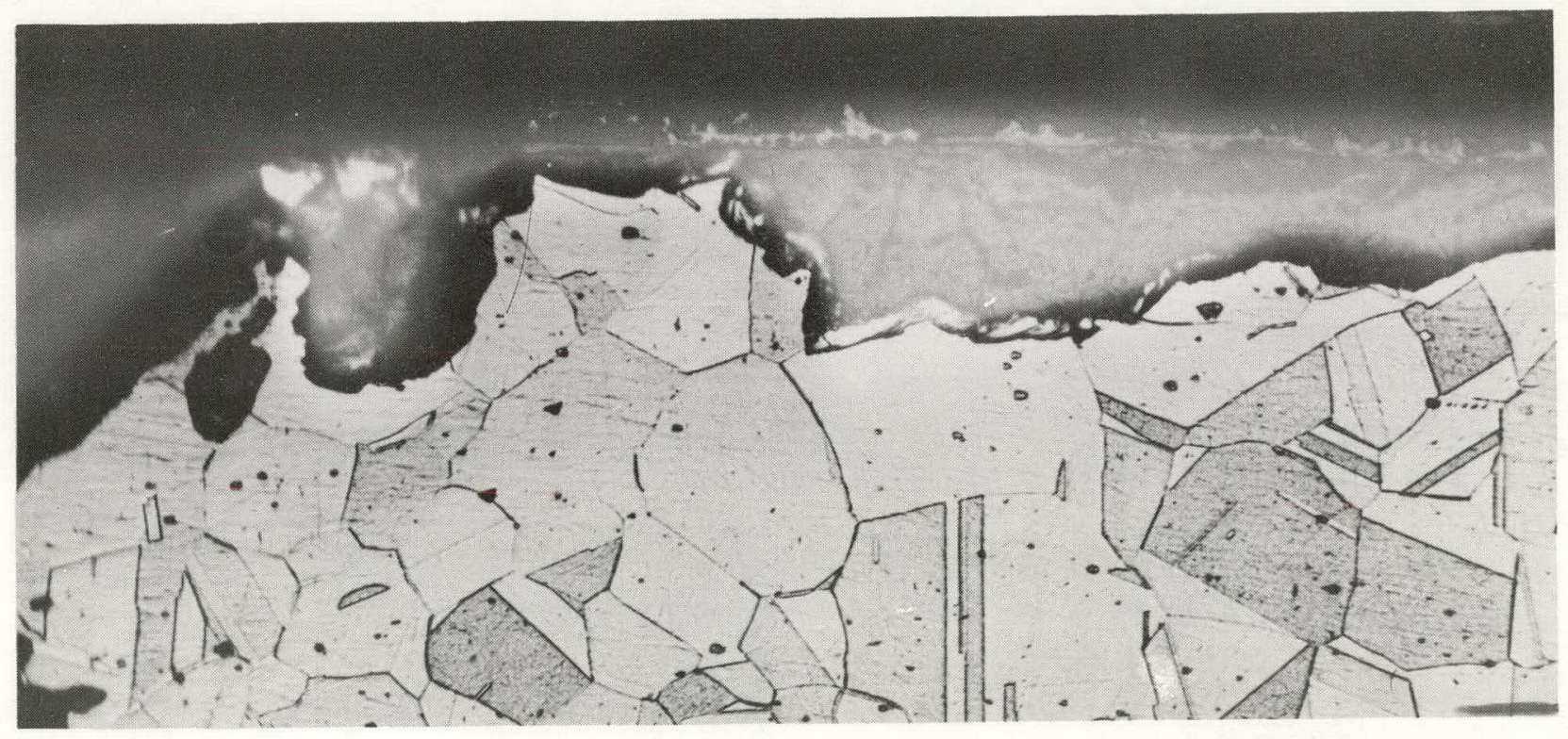

Cowan-Dean etch 350x Neg. \#218

rig. 9 - Alloy 60 (15 Fe - $65 \mathrm{Ni}$ - $20 \mathrm{Cr}$ ) stressed at a 40,000 psi uncorrected stress exposed at $600^{\circ} \mathrm{F}$ to (above) double-distilled deaerated water and (below) to water + 0.1 w/O NaCl + 100 psi oxygen over pressure. 


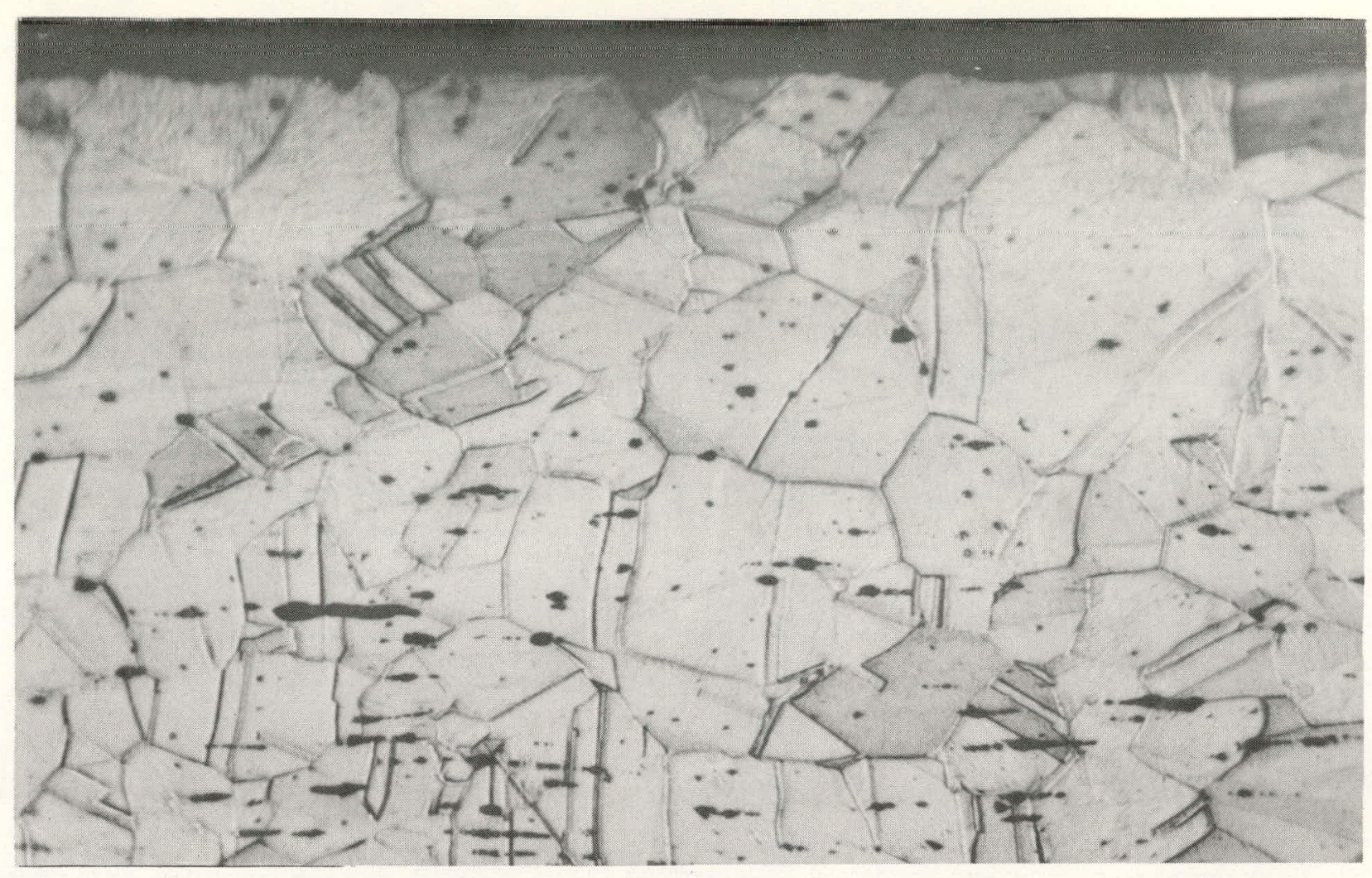

Cowan-Dean etch 350x Neg. \#219

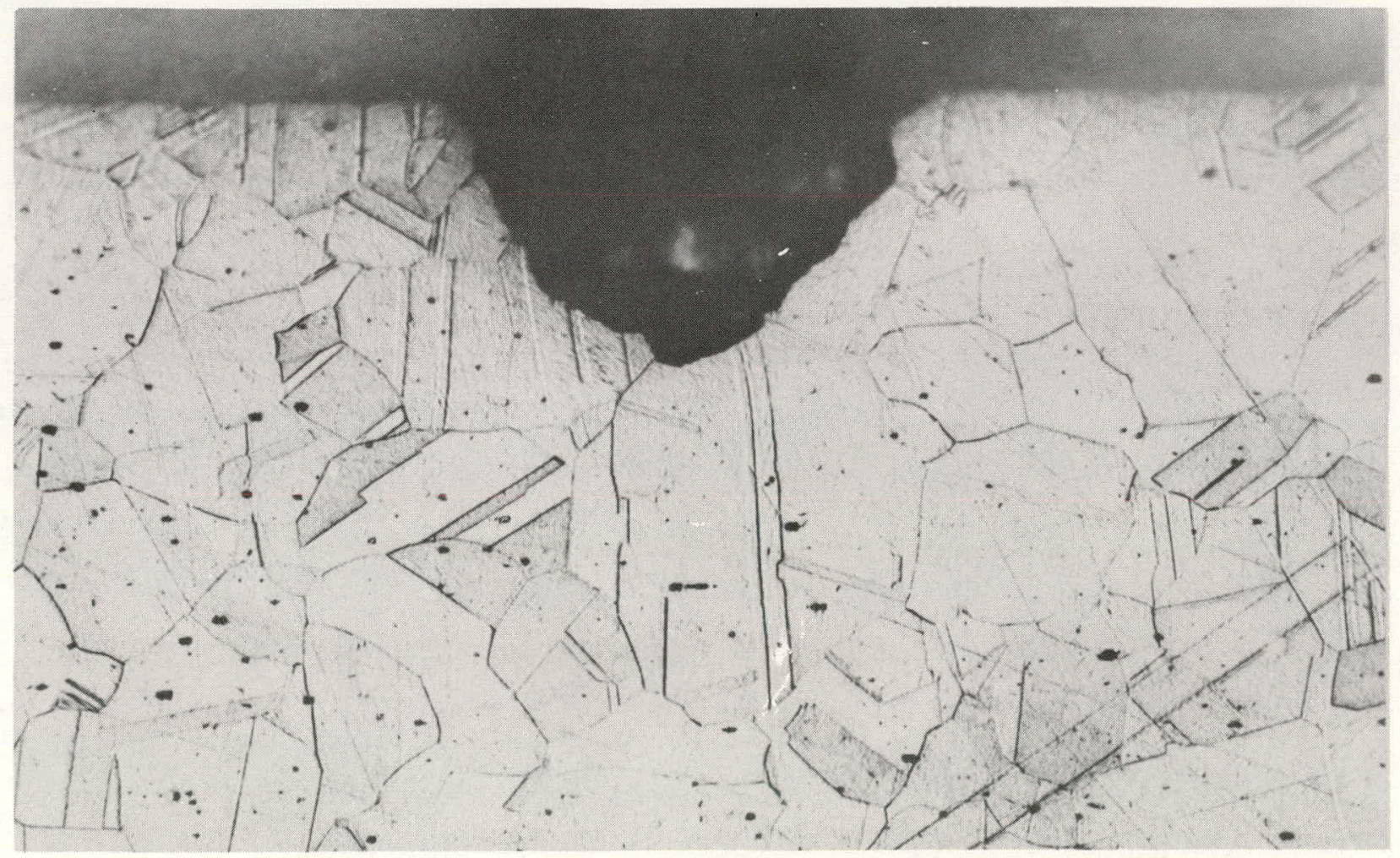

Cowan-Dean etch 350x Neg. \#221

Fig. 10 - Alloy 62 (80 Ni - $20 \mathrm{Cr}$ ) stressed at a 40,000 psi uncorrected stress exposed at $600^{\circ} \mathrm{F}$ to (above) double-distilled deaerated water and (below) to water + $0.1 \mathrm{w} / \mathrm{O} \mathrm{NaCl}+100$ psi oxygen over pressure. 


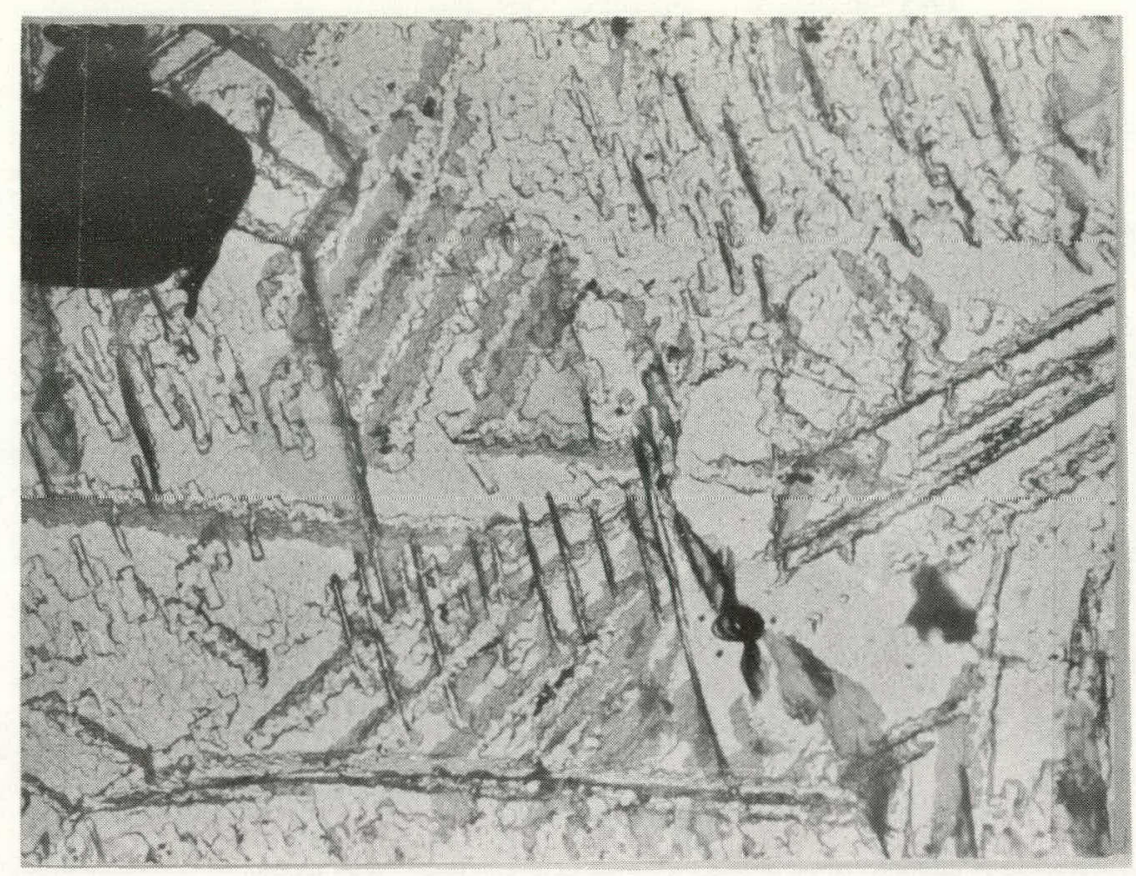

$$
5000 x \quad \text { Neg. \#2-22 }
$$

Fig. 11 - Type 304 stainless steel after $30 \mathrm{~min}$. at 40,000 psi in boiling $\mathrm{MgCl}_{2}$. Specimen in as-received condition. Electron photomicrograph of oxide film removed by bromine dissolution.

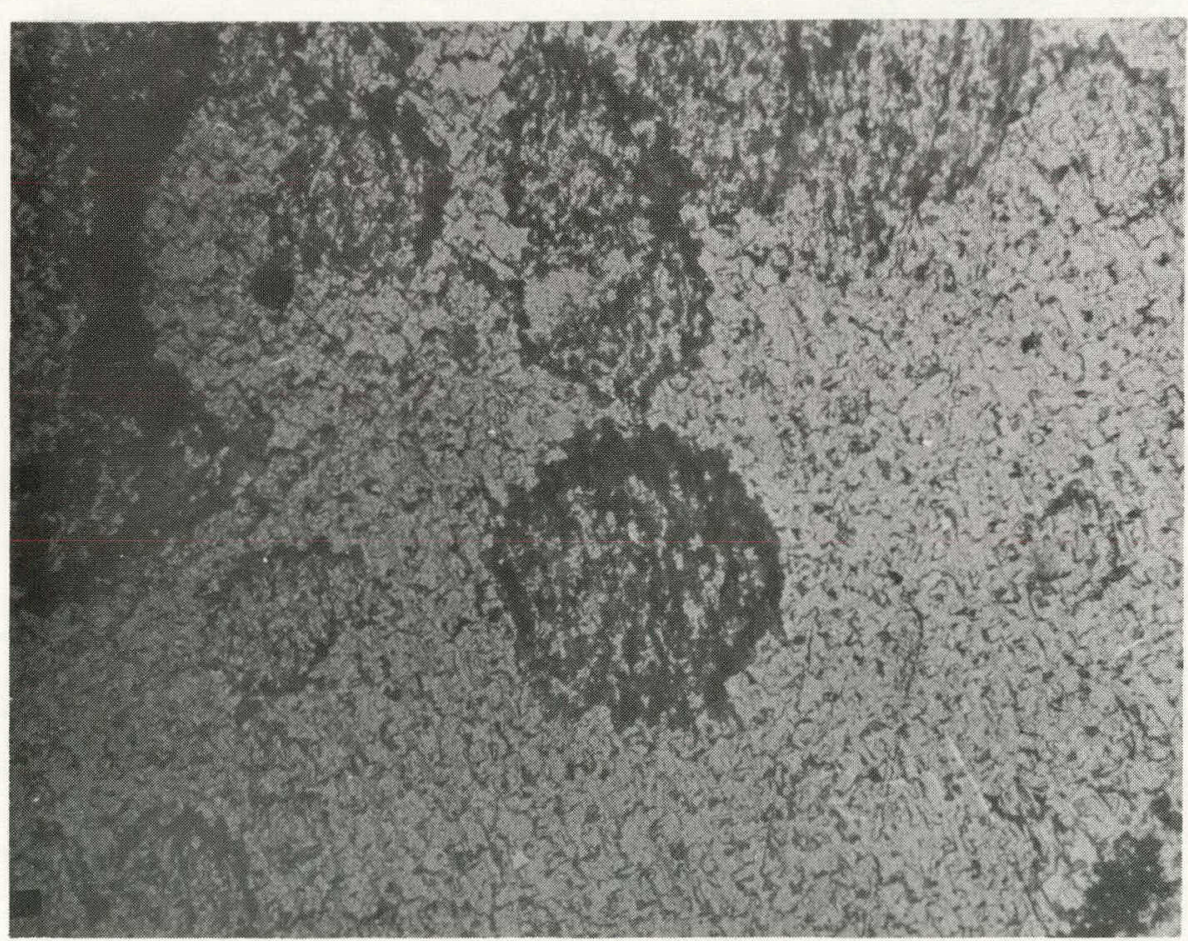

$$
\text { 4000x Neg. \#5-14 }
$$

Fig. 12 - Type 304 stainless steel after 60 min. at 25,000 psi in boiling $\mathrm{MgCl}_{2}$. Specimen is fully annealed. 


\section{ELECTRON METALIOGRAPHY}

Work continues aimed at characterizing the details of surface structure of specimens exposed to environments which promote stress-corrosion cracking. The purposes of this work are to (a) elucidate some of the micro-details of initial stages of surface attack and (b) determine whether certain surface structures can be correlated with susceptibility to cracking.

Surface studies using bromine stripping of oxide films are under way and surfaces of several commerical stainless steels and high-nickel alloys have been examined. The specimen in a stressed condition is first exposed to boiling $\mathrm{MgCl}_{2}$ for a given length of time. The specimen is then oxidized for 45 minutes at $800^{\circ} \mathrm{F}$ in $\mathrm{NaNO}_{3}-\mathrm{KNO}_{3}$ salt. The film is stripped with a bromine (2-8\%) methanol solution and then is viewed in the electron microscope.

The alloys examined to date are Type 304 stainless, Type 309 stainless, Type 310 stainless, Incoloy-800, Incoloy-825, and Inconel-600. The above materials have been studied in the as-received condition and Type 304 and 309 in the annealed condition. Typical observed structures are shown in Figs. 11-15. There appear to be obvious similarities and differences in various structures. For example, the as-received stainless steels show similarities. There are relatively long parallel grouping which may be due to martensite plates or defect structure at slip lines. There is a background structure, more apparent in annealed than in as-received, which has the appearance of dissolution ledges. Finally (most pronounced in Type 304) there are what appear to be spikes (see Fig. 11) extending from the parallel structure. These spikes may be the result of preferential tunneling attack, as has been suggested by some investigators, or may be related primarily to a surface attack. Future studies are planned to clarify these questions.

The annealed Type 304 and 309 appear generally similar, as shown in Figs. 12 and 14. There is a background of ledge-like structure common to both materials. In addition, there are dark circular "blobs" which appear to be pits. They may be related to some of the preferential oxidation seen in Figs. 1-8.

The higher Ni alloys shown in Figs. 16-18 exhibit fewer structural details having the regularity observed in the stainless steels above. There is evidence of irregular boundaries and some extracted precipitates. In the Inconel-600 there is evidence of square structure, possibly etch pits. There is little regularity in the structural detail of Incoloy-825, although some evidence of dissolution, as indicated by a wavelike structure, exists.

\section{ELECTROCHEMICAL STUDIES}

Anodic polarization equipment has been assembled and checked out. An important feature of this equipment is a continuous recording system capable of covering seven orders of magnitude in current density. The capability to obtain reproducible data and to obtain important correspondences in results from 


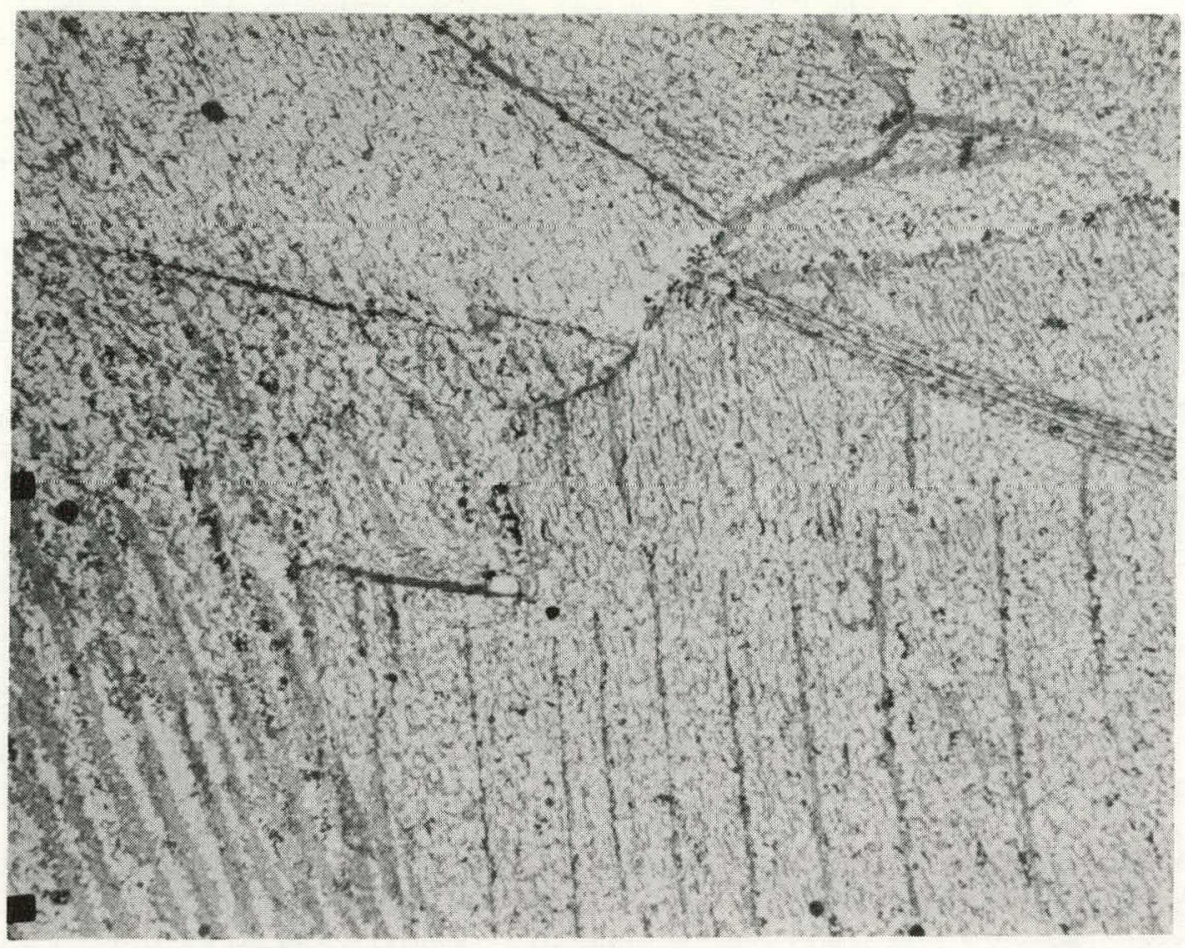

$$
\text { 4000x Neg. \#5-19 }
$$

Fig. 13 - Type 309 stainless steel after 60 min. exposure at 25,000 psi in boiling $\mathrm{MgCl}_{2}$. Specimen in as-received condition.

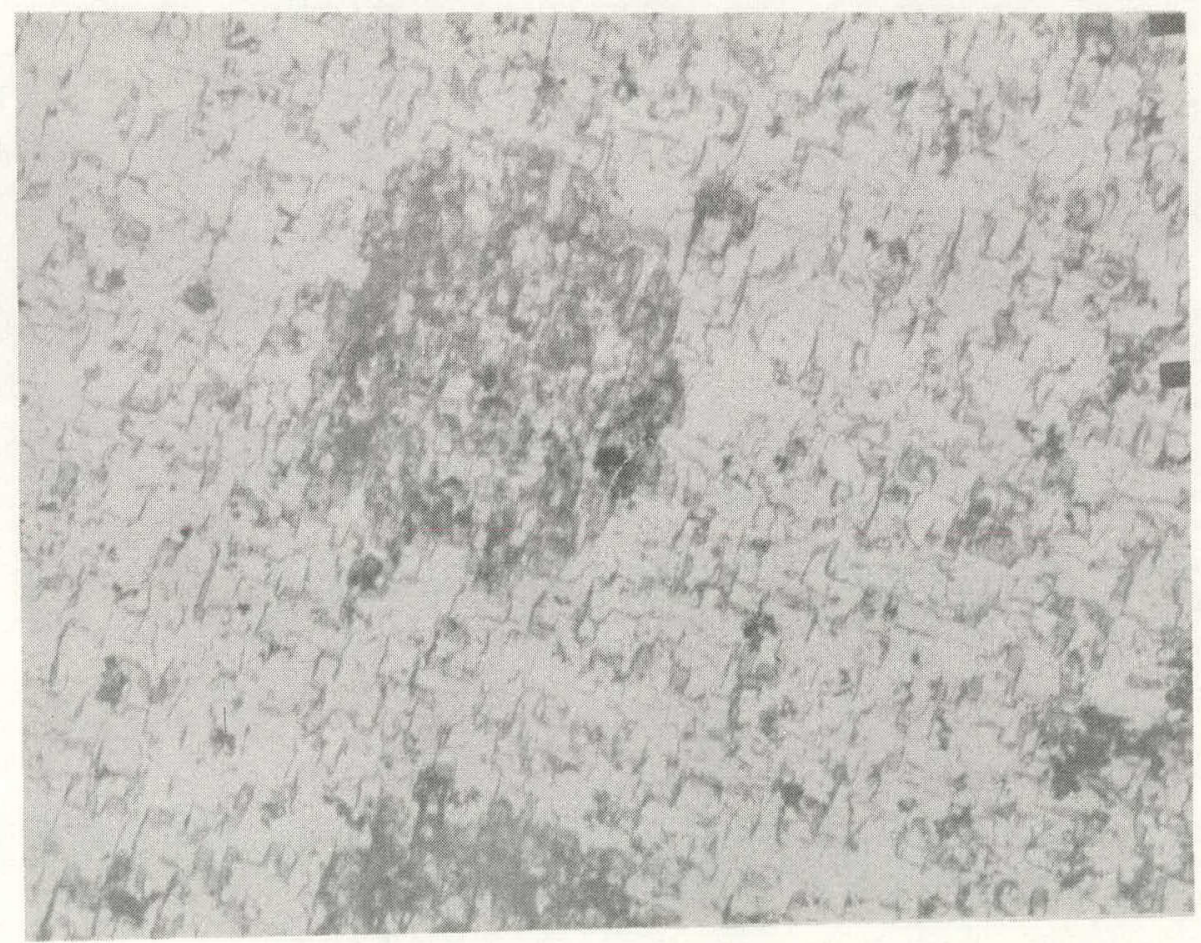

\section{$8000 x \quad$ Neg. \#5-27}

Fig. 14 - Type 309 stainless steel after 60 min. exposure at 25,000 psi in boiling $\mathrm{MgCl}_{2}$. specimen in fully annealed condition. 


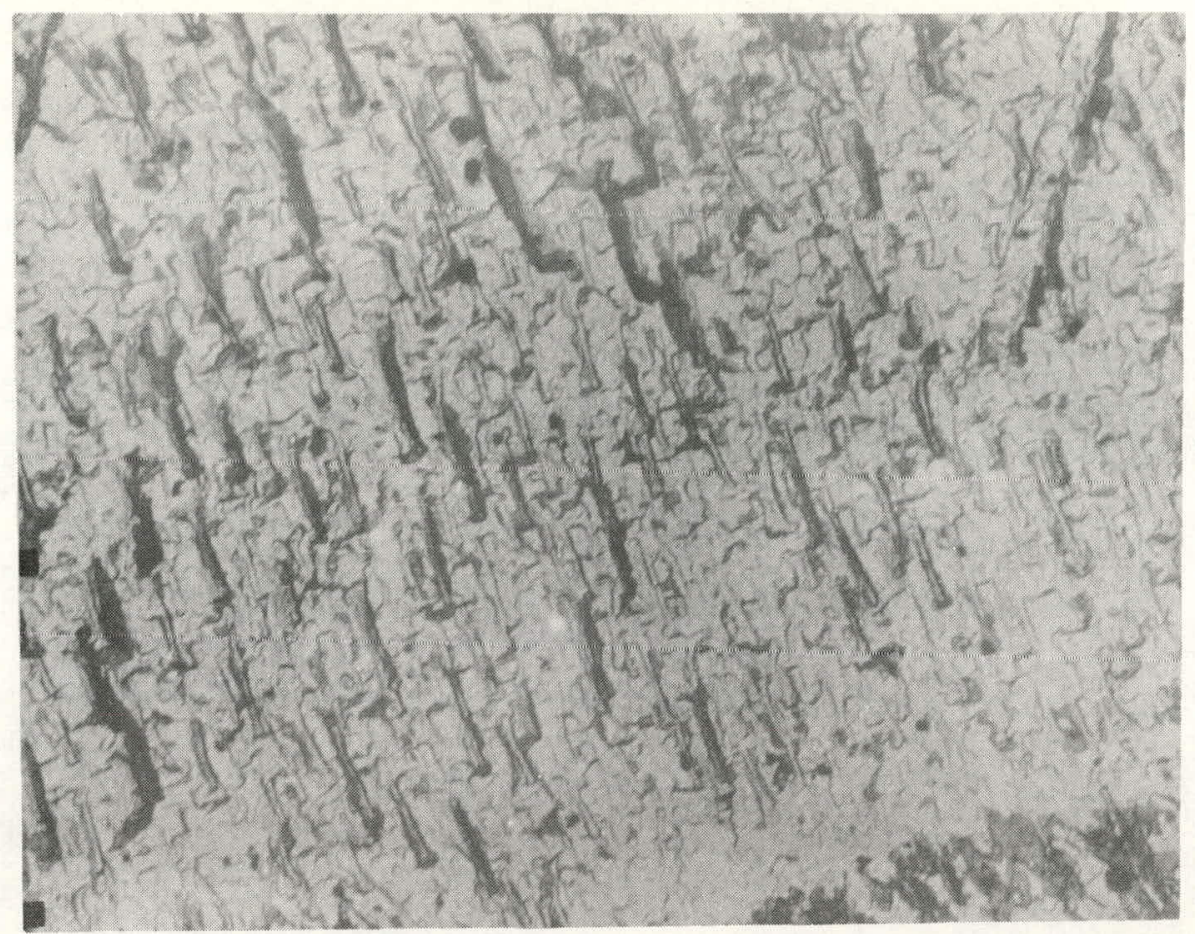

$8000 x \quad$ Neg. \#7-22

Fig. 15 - Type 310 stainless steel exposed for 100 min. at 40,000 psi to boiling $\mathrm{MgCl}_{2}$. Specimen in as-received condition.

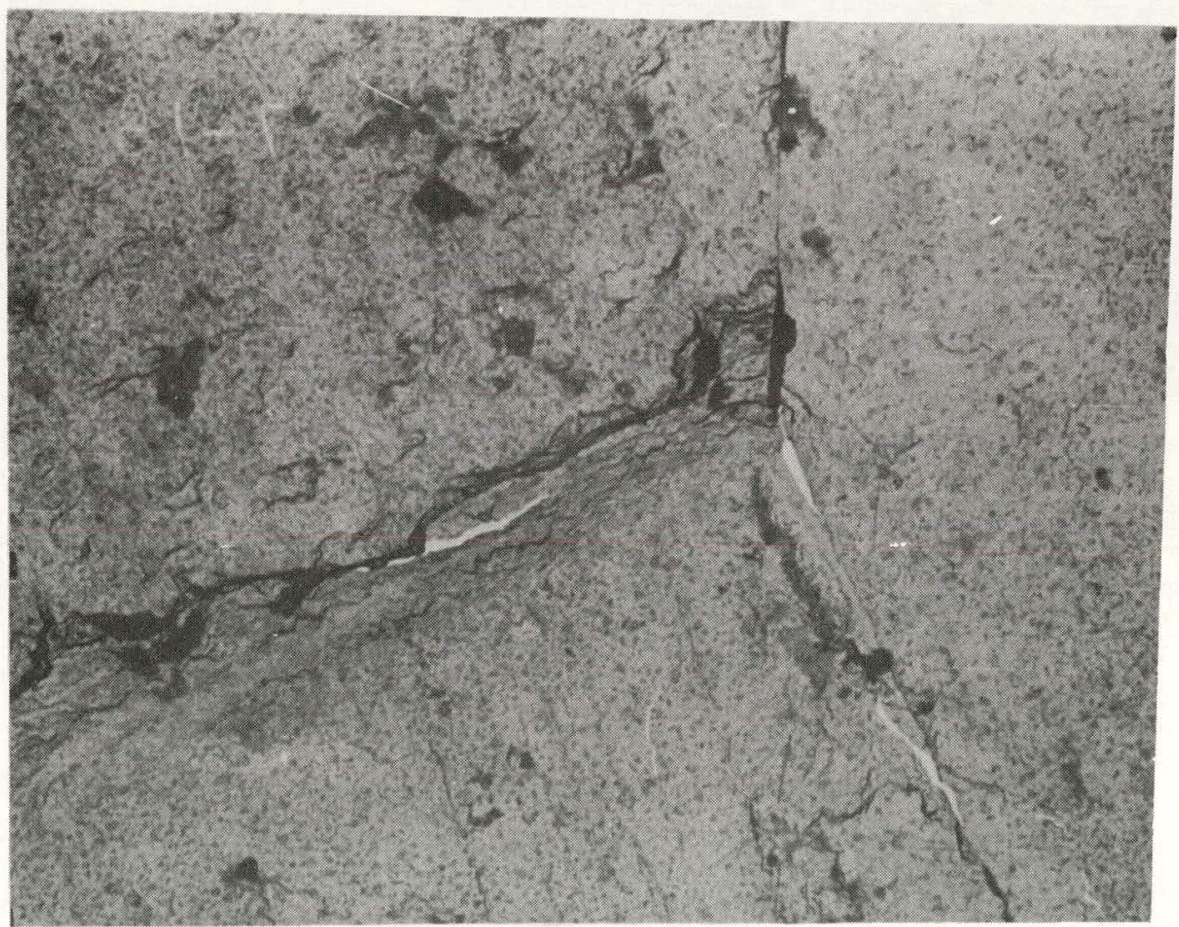

8000x Neg. \#7-18

Fig. 16 - Incoloy-800 exposed 100 minutes at 40,000 psi to boiling $\mathrm{MgCl}_{2}$. Specimen in asreceived condition. 


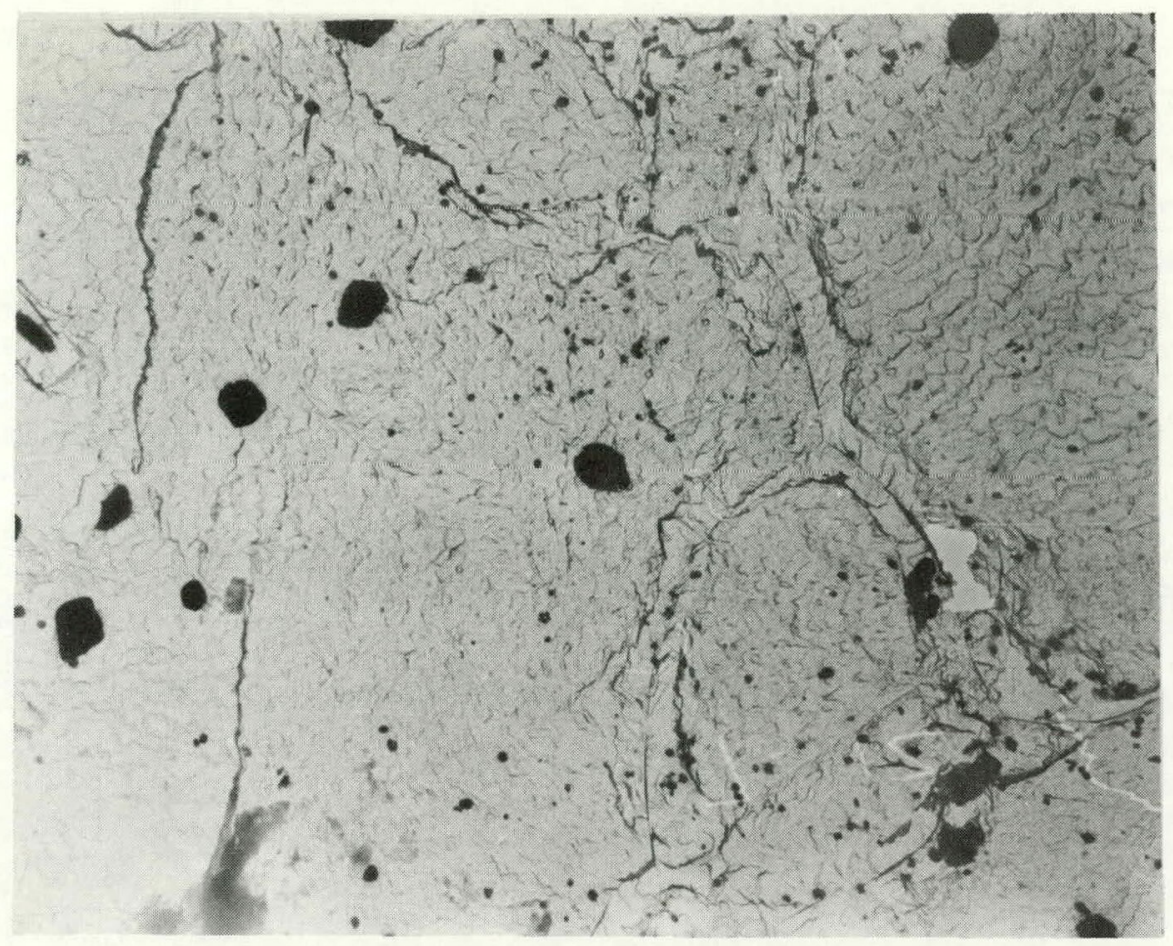

4000x Neg. \#7-12

Fig. 17 - Incoloy-825 exposed for 100 minutes at 40,000 psi to boiling $\mathrm{MgCl}_{2}$. As-received.

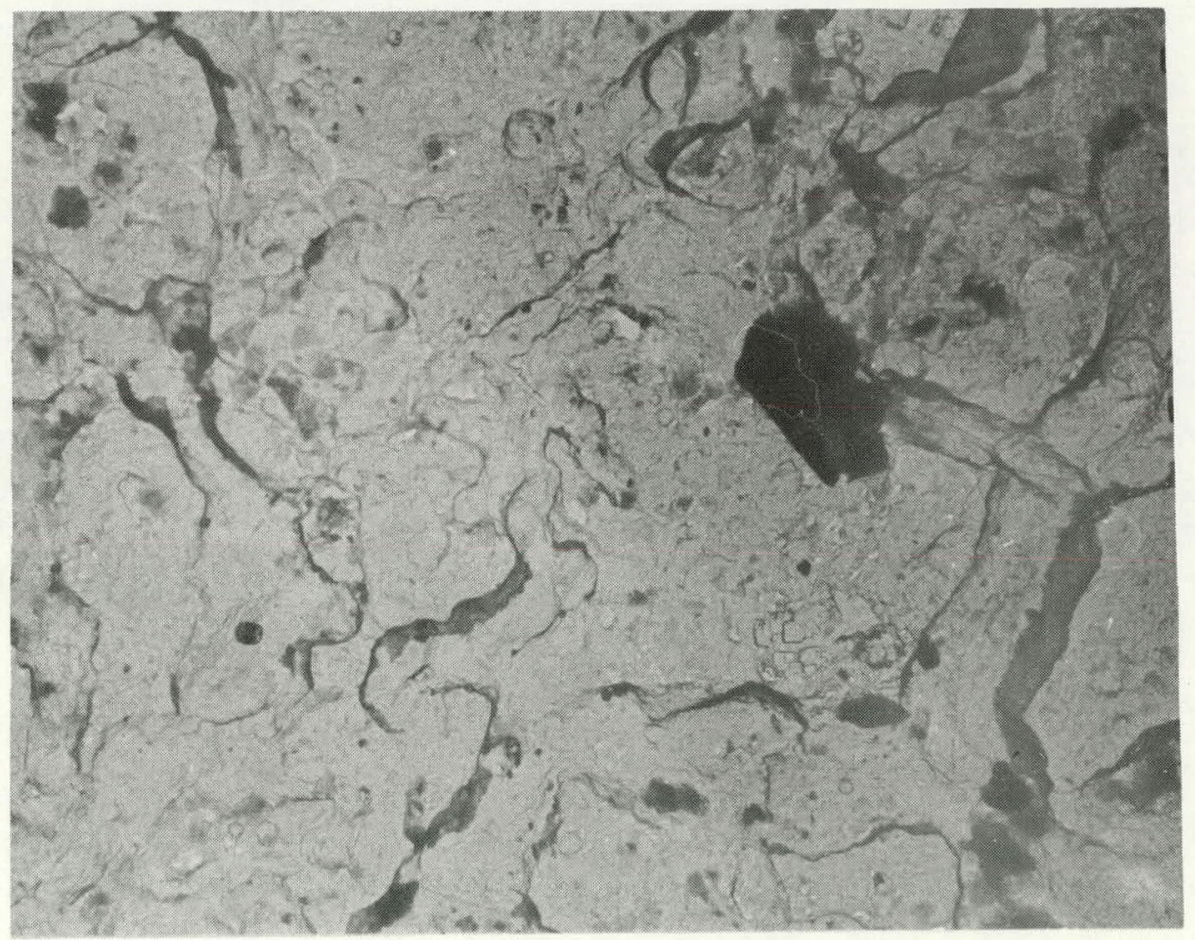

8000x Neg. \#6-23

Fig. 18 - Inconel-600 exposed for 100 minutes at 40,000 psi to boiling $\mathrm{MgCl}_{2}$. As-received. 
different voltage scanning rates has been established. The next quarterly progress report will include a detailed discussion of the system being used and results from scoping studies.

\section{ACKINOWLEDGEMENTS}

The assistance being arranged by the following organizations is gratefully acknowledged:

Battelle Memorial Institute -- melting of ingots and preparation of specimens

The Duriron Company, Inc., -- chemical analyses

International Nickel Company, Inc., -- donations of Ni-270 melting stock and commercial alloys

United States Steel Corp., (Monroeville) -- donations of commercial alloys

United States Steel Corp., (American Steel and Wire Division) -donations of wires of commercial stainless steels

Stellite Division of Union Carbide -- donations of wires of Hastelloytype alloys

The assistance of Messrs. Farrar, DeLuca, Cowan, Postle, and Simmons in the metallography, x-ray studies, performance of experiments, and construction of equipment is acknowledged.

Technical contributions to this report were made by Messrs. R. I. Beauchamp, R. Cochran, M. Dean, T. Smith, J. R. Upp, and R. W. Staehle.

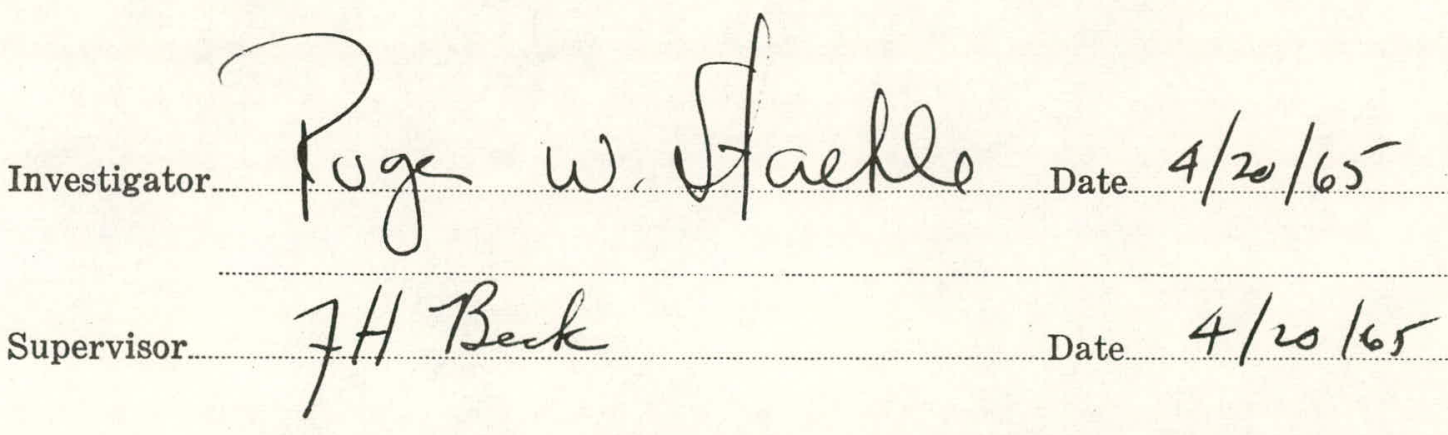

For The Ohio State University Research Foundation

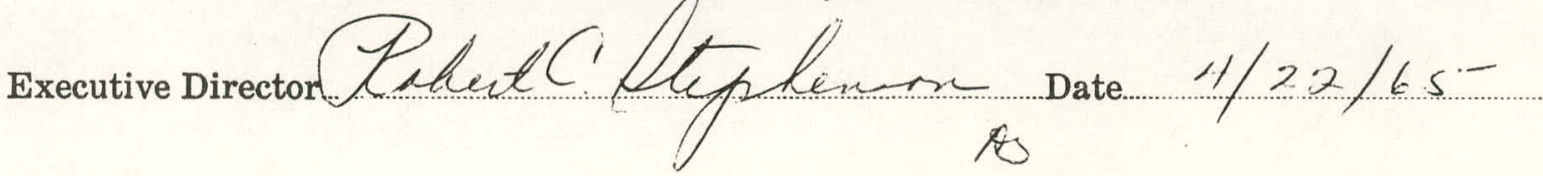


